\title{
Bank business models, negative policy rates, and prudential regulation
}

\section{Roberto Savona ${ }^{1}$}

Received: 22 June 2020 / Accepted: 16 September 2021 / Published online: 13 October 2021

(c) The Author(s) 2021

\begin{abstract}
Using data from Italian banks over the period 2011-2017, we study how negative interest rate policy and prudential regulation impact on bank business models. We report four key findings. First, banks shifted into retail- and market-oriented business models. Second, high- and low-deposit banks reduced loans and increased security/liquid assets; only market-oriented banks expanded lending. Third, interest rate income compression induced by negative rates has been substantial for the Italian banking system as a whole, although retail banks seem to have suffered less. Fourth, non-interest incomes played a compensatory effect. The portfolio reshuffling, as we observed for wholesale and retail banks (less lending and more securities/liquid assets), is related to the goal of reducing risk exposures and, in turn, the connected capital absorption required by prudential regulation.
\end{abstract}

Keywords Negative interest rate policy · Bank lending $\cdot$ Portfolio rebalancing

JEL Classification C33 $\cdot$ E52 $\cdot$ G21 $\cdot$ G11 $\cdot$ L51

\section{Introduction}

Banks are fundamental institutions for the transmission of monetary policy to the economy. Lower interest rates are assumed to stimulate bank lending, increase risk taking, and ultimately, provide a stimulus for the real economy. This is, essentially, the reasoning behind the decision taken by the ECB in June 2014 to cut the rate on its deposit facility (deposits that banks make with the Eurosystem) by 10 basis points into negative territory. Afterwards, in September 2019, the ECB Governing Council lowered again the interest rate on deposit facility by further 10 basis points to $-0.50 \%$,

Roberto Savona

roberto.savona@unibs.it

1 Department of Economics and Management, University of Brescia, C/da S. Chiara 50 - 122, Brescia, Italy 
while introducing a zero interest rate on part of the banks' liquidity reserves ("tiering") in order to attenuate the risk, pointed out by some observers, that increasingly negative interest rates on the deposit facility could have counterproductive effects on banks' balance sheets and, in turn, on lending.

Understanding how negative interest rates impact on bank profitability and banks' incentives to lend and adjust their assets and liabilities, when prudential regulation tends to be more binding, is a priority for monetary and banking research (Eisenschmidt and Smets 2019; Eggertsson et al. 2019). This is because we are entering a time where negative interest rates are becoming the new normal within a more severe capital and liquidity regulation. Moreover, a clear consensus about the impact on the banking system is still missing, ${ }^{1}$ as the effects of negative interest rates can differ across countries (Molyneux et al. 2019). Again, negative interest rates policy effectiveness is under scrutiny not only for countries that already adopted such a measure, ${ }^{2}$ but also for those where the policy has never been used (yet), as in the U.S., in which monetary authorities are "embarking upon a yearlong conversation about its monetary policy framework". 3

Accordingly, an extensive empirical research is essential to better understand how these tools impact on the different banking systems.

In this paper, we explore how negative interest rates policy affected the Italian banking sector over the period from 2011 to 2017. Italy is of primary interest for the analysis of negative interest rates policy impacts for at least four reasons. First, it is a large European economy where banks play a central role in funding firms and households. Second, the Italian banking sector was under pressure from the severe sovereign debt crisis in 2011, which heightened the need to urgently adapt to the post-crisis regulation (Basel III) that introduced tighter capital requirements. Third, as underlined by Bottero et al. (2019), Italy is part of a monetary union, and their banks are affected by the monetary policies of the ECB for the entire euro area. Fourth, as we show in Table 1 , after 2014, when negative interest rate became operational, the retail deposit rates have fallen substantially, almost nearing the zero-lower bound (from 0.32 percent in 2013 , to 0.05 percent in 2018), ${ }^{4}$ thus leading to a question on how banks responded to the effects of the negative policy rates on the net-interest margin compression. In this regard, theoretical arguments suggest the possibility of two main transmission

\footnotetext{
1 The Financial Times in September 18, 2019 writes: "Negative interest rates were first introduced in the region in June 2014 to boost a flagging economy by nudging banks into lending more money, rather than leaving excess liquidity languishing at the central bank. But its knock-on effect has been to further dent the already-strained earnings of Europe's banks, which are holding a combined $€ 1$.9tn of reserves to satisfy post-crisis regulations." See https://www.ft.com/content/93015730-d960-11e9-8f9b-77216ebe1f17.

2 Denmark, Japan, Sweden, Switzerland, and the euro area.

3 Bloomberg, January 7, 2019 (https://www.bloomberg.com/news/articles/2019-01-07/summers-rejectsnegative-rates-as-potential-crisis-fighting-tool).

4 Moreover, by exploring data from the "Survey on the cost of bank accounts" published by the Bank of Italy, the direct cost charged, on average, on retail bank accounts (see Table 1) has risen since 2016, thereby pushing the net retail deposit rate below zero. Indeed, as we show in Table 1, the ratio between cost and average account size reached 1.91 percent in 2018, with values around 1.52 percent for the years 2013-2014, and 1.44 percent for the years 2015-2017. These values exceed the nominal retail deposit rates, thereby pushing the net rates below zero. The national press stressed the point with headlines such as "Here's how banks charge negative rates on checking accounts" (Il Sole 24 ore, December 9, 2019: https://www.ilsole24 ore.com/art/ecco-come-banche-fanno-pagare-tassi-negativi-conti-correnti-ACMFGu2).
} 
Table 1 Deposit rates and cost of bank accounts owned by households in Italy: Average values over the period 2011-2018

\begin{tabular}{lllll}
\hline & Deposit Rate (\%) & Size (in euros) & Cost (in euros) & Cost/size (\%) \\
\hline 2011 & 0.360 & n.a & n.a & - \\
2012 & 0.362 & n.a & n.a & - \\
2013 & 0.319 & 5,400 & 81.90 & 1.517 \\
2014 & 0.245 & 5,400 & 82.20 & 1.522 \\
2015 & 0.162 & 5,400 & 76.50 & 1.417 \\
2016 & 0.101 & 5,275 & 77.60 & 1.471 \\
2017 & 0.065 & 5,543 & 79.40 & 1.432 \\
2018 & 0.050 & 4,546 & 86.90 & 1.912 \\
\hline
\end{tabular}

The table reports the average retail deposit rate (Deposit Rate), the average size of bank accounts of households (Size), and the average cost of bank accounts owned by households (Cost) over the period 2011-2018. The ratio Cost/Size is a proxy of the direct cost, on average and on an annual basis, charged by banks over the accounts owned by households in Italy. Data on deposit rates come from the "Statistical Database" of the Bank of Italy and are available at this link: BdI-Rates. Data on Size and Cost come from the "Survey on the cost of bank accounts" published by the Bank of Italy and are available at this link: $\underline{\text { BdI-Cost }}$

mechanisms: (1) a credit supply compression, with an increase in risk-taking (Heider et al. 2019) and a weakened pass-through to loan rates, especially for banks that are more dependent on retail deposits (this is the retail deposits channel); (2) a portfolio rebalancing from liquid assets to credit, thereby contrasting the net-interest margin compression, moving from safe assets, with low/negative yields, towards higher-yield assets (this is the portfolio rebalancing channel).

As a result, our analysis of the Italian banking sector during the period when the ECB's monetary policy entered into negative interest rates territory provides an important piece of evidence to gauge the unconventional monetary policy impacts.

How banks change their incentives to lend, performance, financial resilience and risk attitude seems to depend on their business model connotation. As noted by Nucera et al. (2017), in an environment of negative interest rates banks might benefit via fewer non-performing loans/increases in asset prices, but they can also suffer via squeezed interest rate margins for new business. Banks are extremely heterogeneous in terms of size, institutional and business organization, funding and investments choices, and this diversity is a crucial element to take into account for the study of the (different) impact assessments of unconventional monetary policies on banks. ${ }^{5}$

In this paper, we run an in-depth analysis of the negative policy rates impact on Italian banks, which we classify into distinct bank business models based on the balance sheet characteristics. More specifically, we identify three business models according to much of the literature on this topic (e.g., Ayadi et al. 2011; Ayadi and De Groen 2014; Grossmann and Scholz 2018; Roengpitya et al. 2014): (i) retail-funded

\footnotetext{
5 To identify bank business models, existing approaches commonly use cluster analysis based on single (static) cross-sections of year-end data (e.g., Roengpitya et al. 2014; Ayadi et al. 2011; Ayadi and De Groen 2014), also extended to panel framework, thereby pooling information over time (Lucas et al. 2019).
} 
banks, characterized by high shares of loans and deposits; (ii) capital market-oriented banks, which include banks with substantial trading assets and interbank funding; and (iii) wholesale-funded banks, whose asset profile is similar to the one of the first group, while showing a funding structure dependent less on deposits and more on long-term funding. We collect data on balance sheets for 125 Italian banks over the period from 2011 to 2017, and compare the actions of retail and market-oriented banks with those of wholesale banks (our "control group") in a 'difference-in-differences' panel regression framework. In this way, we are able to isolate the behavior adopted by retail and market-oriented banks, and induced by unconventional monetary policy measures, from other bank business model differences. Moreover, we try to disentangle the impact on bank profitability and portfolio rebalancing attributable to NIR, proxied by a dummy variable taking the value 1 when negative rates became operational, and the prudential regulation (Basel III), proxied by the Tier 1 capital ratio, while controlling for other bank-specific controls. The sample accounts, on average, for more than 80 percent of the total assets of all banks operating in Italy over the period 2011-2017, and includes all legal forms permitted by law in Italy, ${ }^{6}$ covering small to medium, and large to systemically important institutions, thereby obtaining a sample that closely matches the characteristics of the entire banking population in Italy. By doing so, we offer a comprehensive empirical assessment for almost the entire Italian banking system on how the supply of bank credit was affected by the negative interest rates and how banks modified their balance sheet assets, also exploring the impact on bank profitability.

Depending on which business model is at play, negative policy rates could impact in different ways. In principle, retail banks should be expected to suffer the most in terms of interest margin squeeze, as they rely predominantly on deposits, upon which the adjustment of the interest rate mark-down tend to be reduced. By contrast, low deposit banks with sufficiently diversified income streams can be more flexible in their asset and liability management, afterwards mitigating the interest-rate margin reduction through portfolio rebalancing.

The assets and liabilities rebalancing towards higher-yielding assets takes place conditionally on the capacity and the willingness to take on more risk relative to the bank solvency. This creates a tension between the search for compensating yields, on the one hand, and the solvency requirements, on the other. From this perspective, bank capital is viewed as a loss-absorbing buffer that enhances bank solvency, thereby assuming a key role in driving bank balance sheet adjustments. ${ }^{7}$

\footnotetext{
6 The legal forms admitted in Italy are: public limited banks (società per azioni), cooperative banks (banche di credito cooperativo) and popular banks (banche popolari). As of December 2017, 89 percent of all banks' assets in Italy were public limited banks; cooperative banks accounted for 7 percent and popular banks for 3 percent of the total. See 'Banks and Money: National Data,' Banca d'Italia, Statistics Series (https://www. bancaditalia.it/pubblicazioni/moneta-banche/2018-moneta/index.html). Although in terms of total assets the public limited banks are predominant in Italy, cooperative banks represent the largest category in terms of number of units with 280 banks versus 52 joint stock companies and 15 popolari banks. See 'Annual Report for 2017', Banca d'Italia, pp. 161-162 (https://www.bancaditalia.it/pubblicazioni/relazione-annuale/2017/ index.html).

7 Starting from this argument, Gambacorta and Shin (2018) investigate major international banks from advanced economies over the period 1994-2012, finding that higher bank capital, proxied by equity-tototal assets ratio, is associated with lending growth.
} 
Our results suggest that the negative policy rates had an expansionary effect on credit supply for market-oriented banks, which was strong enough to offset the substantial lending contraction of wholesale banks. Wholesale and retail banks implemented a portfolio strategy that led to less lending and more security/liquid assets in order to reduce risk exposures, thereby adapting to the new liquidity and capital regulation framework introduced in January 2104 with the Capital Requirements Directive (CRD IV) and the Capital Requirements Regulation (CRR), both conceived to enhance the resilience of the European financial system. This result is consistent with Conti et al. (2018), who find evidence of large and persistent shocks to bank capital induced by regulatory/supervisory pressure, with significant negative effects on loan supply in the Italian banking system over the period 1993-2015. Instead, market-oriented banks, with adequate liquid assets over the period 2011-2013, have been more risk-taking, as the capital adequacy (Tier 1 ratio) was, on average, relatively high before (and after) the negative interest rates policy.

On the profitability side, we observe significant interest rate margin compression as a whole, though retail banks seem not to have suffered from the same negative impact experienced by wholesale and market-oriented banks. Banks that suffered most from net interest rate compression, primarily wholesale banks, have tried to compensate their losses through non-interest income, namely, fees and commissions. Thanks to this compensatory effect, our evidence supports the hypothesis that the overall effect of negative rates policy on bank profitability in Italy has been broadly neutral over the period 2011-2017.

From 2011-2013 to 2014-2017, the business models changed substantially with a strong polarization towards retail- and market-oriented banking models. This structural change is to ascribe to both the negative policy rates and the new regulatory framework introduced with Basel III, which induced banks to become strongly deposit-dependent and relatively more focused on trading and liquid assets. As a result, the Italian banking system became less exposed to risk, as proven by the substantial and significant reduction of risk-weighted assets, in particular for retail and wholesale banks, and more financially resilient, as documented by the average Tier 1 ratio, which ranged between 15.84 and 22.40 percent in the years 2014-2017.

We show that banks with substantial trading and liquid assets, namely, marketoriented banks, increased their lending after the negative policy rates became operational. Moreover, we suggest that high- versus low-deposit characterization should combine with bank assets riskiness and capital adequacy: wholesale and retail banks reduced lending and increased the share of securities/liquid assets because of the goal of reducing their risk exposures and, in turn, the capital absorption required by prudential regulation. Such a characterization does not completely support the retail deposits channel, which would imply less credit by banks with high deposits in a low-rate environment because of the net interest margin compression. According to this view, since retail banks are reluctant to pass negative rates onto depositors, negative policy rates may compress banks' profits and erode capital (Heider et al. 2019; Eggertsson et al. 2019; Kumhof and Wang 2020). Instead, we find that retail banks were not experienced a significant margin compression such as the one that occurred to wholesale and market-oriented banks, which are both less dependent on retail deposits. 
From a theoretical perspective, these findings are consistent with the debt overhang problem (Myers 1977; Admati et al. 2018). As noted in Admati and Helwig (2019), if banks choose to compress lending when asked to increase equity requirements, the reason might be because of their efforts at "risk weight management". In other words, banks tend to reduce loan share because of the preferential regulatory impact on securities (particularly government bonds). The problems due to debt overhang become substantial with the bank leverage, since banks with less leverage are not inclined to contract lending due to debt overhang. In line with this prediction, we then conjecture that wholesale banks suffered the most from debt overhang problems and were extensively engaged in managing their asset risk weight by investing more in securities and liquid assets. Instead, market-oriented banks were better capitalized and they were thus in a position to continuing lending also in a period of negative policy rates and binding capital and liquidity regulation.

The remainder of the paper is organized as follows. Section 2 reviews the relevant literature on how monetary policy impact on banks' behavior when policy interest rates are negative. Section 3 introduces the methodology. Section 4 presents the data and preliminary statistics on bank business model characteristics before and after the negative interest rate policy. Section 5 reports and interprets the empirical results. Section 6 wraps things up.

\section{Literature review}

The existing literature on how changes in monetary policy impact on banks' behavior, when policy interest rates are reduced to levels below zero, can be divided into three main strands. First, the theoretical modelling of monetary policy transmission through banks. Second, the empirical literature on how changes in monetary policy impact on banks' behavior when policy interest rates are reduced to levels below zero. Third, how banks' business models adapt in a low interest rate environment. Our study connects and contributes to all three of these research lines.

On the theoretical modelling of monetary policy transmission, our paper relates to Brunnermeier and Koby (2019) and Campos (2019). Brunnermeier and Koby (2019) emphasize the importance of the balance sheet structure and the net worth of intermediaries for the transmission of monetary policy. ${ }^{8}$ They claim that below some level of the (not necessarily zero) policy rate, what they call "reversal rate", an interest rate cut might be expansionary in one region and contractionary in another, due to the negative effects of lower profitability on bank capital and the associated bank lending contractions. The authors introduce a model of monetary policy transmission through banks, arguing that following an interest rate cut, two opposing forces affect banks' net worth: the "positive" force comes from capital gains on assets with long-term fixedrate coupon payments, while the "negative" one comes from the banks' net interest income shrinkage due to the rate cut. They then show that the level of endogenous reversal rate depends on the magnitudes of capital gains, the overall capitalization

\footnotetext{
8 Brunnermeier and Koby (2019) fit into the long-standing literature on "balance sheet" and "bank lending" channels of monetary policy traced back to Bernanke and Blinder (1988), Bernanke and Gertler (1995), and Van den Heuvel (2006), among others.
} 
of banks, the strength of leverage constraints faced by banks, and the deposit supply elasticity. The empirical results of our paper benefit from this theoretical framework. Indeed, since we find that the negative policy rates did not lead to a lending contraction as a whole, according to the Brunnermeier-Koby's model we can then conclude that over the period 2011-2017 the so-called reversal rate was not reached in Italy.

Campos (2019) introduces a New Keynesian DSGE model where banks intermediate the transmission of monetary policy, showing that lowering interest rates below zero can be less effective than lowering them in positive territory, since deposit rates remain stuck at zero and bank profits are accordingly squeezed. The efficiency of negative nominal rate policy measure is strongly dependent on bank equity, which assumes key importance for lending and for the overall economy. One of the main implications of our paper converges with, and expands upon, the key role assumed by the bank equity, as we find a robust relationship between equity and lending, but only for market-oriented banks. As we discuss in Sect. 6.4, this opens the door to future research on the potential policy recommendations we can draw from an appropriate modelling on how negative interest rates are connected to the economy through banking intermediation.

The contribution of our study to the empirical literature on negative interest rates and banks' behavior relate to the debate that, as recently pointed out by Goodhart and Kabiri (2019), confronts two contrasting views about the role played by monetary policy. On the one hand, a group of economists claim that with negative policy interest rates, the banking channels are supposed to become negative and sufficiently so to have a net negative effect on the economy as a whole, essentially because bank profits drop. On the other hand, a second group of economists claim that expansionary monetary policy did not seriously affect bank profitability and credit supply. Heider et al. (2019) explore the lending activity of high- and low-deposit banks over the period from June 2014 to January 2015, finding that high-deposit banks have reacted to negative rates by decreasing their loan supply and starting to lend to riskier borrowers. Tangentially, Amzallag et al. (2019) find that deposit-funded banks charged higher rates for fixedrate loans after June 2014, while variable-rate loans did not experience the same impact. Instead, Demiralp et al. (2019) ${ }^{9}$ and Albertazzi et al. (2016) document that high-deposit banks expanded loans under negative rates, while Arce et al. (2018) find no evidence, neither in the euro area nor in Spain, that negative rates contracted the supply of credit, and asserted that the "reversal rate" might not have been reached yet. Eggertsson et al. (2019) focus on the case of Sweden and document that once the deposit rate becomes bounded by zero, interest rate cuts into negative territory lead to an increase rather than a decrease in lending rates. Finally, Bottero et al. (2019) study the impact of negative interest rate policy on credit supply in Italy, finding expansionary effects through a portfolio rebalancing channel from liquid assets to credit.

Within this empirical dispute, our evidence suggests that the high- versus lowdeposit characterization should move in tandem with bank assets riskiness and capital

\footnotetext{
9 Demilrap et al. (2019) observe that rate cuts resulting in negative policy rates operate differently from conventional rate cuts, because banks may not be able to charge their retail customers negative rates on their deposits, leading therefore to declining intermediation margins. As a reaction to the profitability compression, banks may change the composition of their balance sheets and/or move towards incomedriven activities to compensate for net-interest margin reductions.
} 
adequacy. In more depth, the portfolio reallocation we document and connect with lending seems related to the goal of containing the capital risk absorption required by the prudential regulation.

Finally, the third line of research to which we connect is on bank business models. Existing papers mostly refer to the relationship between risk and bank characteristics, such as capital (Wheelock and Wilson 2000), funding sources (Demirguc-Kunt and Huizinga 2010), financial innovation and financial market linkages (Boot and Thakor 2010; Mian and Sufi 2009), and diversification (Stiroh 2010). ${ }^{10}$ In these studies, banking business models are mainly explored in relation to their development over the pre- and post-crisis periods, by assessing bank performance and risk dynamics during crisis periods. As for these papers, our study is different since it questions how business models impact on a bank's incentive to lending and on bank profitability when policy rates become negative within a more binding capital and liquidity regulation. When entering into this territory, profitability of banks is under pressure and contractionary effects on bank lending is determined by the bank's reliance on deposits versus wholesale funding and the interest rate sensitivity of bank's assets (Eisenschmidt and Smets 2019). Moreover, banks might lend to riskier borrowers without being fully compensated for it (Heider et al. 2019), also 'searching for yield' with a disproportional demand for high-yielding risky assets (Rajan 2005), which exposes banks to adverse effects on risk taking. Again, Borio et al. (2015) find that the effects on netinterest margin of banks are much stronger at lower levels of interest rates, when the yield curve is unusually flat. Finally, Claessens et al. (2018), note that "the differences between small and large banks in terms of the impacts of interest rate changes on net interest margin and profitability arise in part from differences in the compositions of their assets and liabilities, in the competition for funds and lending opportunities, and in general business models."

Altunbas et al. (2011) show that the effect of business models on bank risk is highly non-linear. On the one hand, riskier banks, which turn out to be undercapitalized, are more sensitive to loan growth, customer deposits and market funding. On the other, high customer deposit-funded banks are more effective in reducing distress. Likewise, market funding increases the probability of distress for the riskiest banks, but has no effect on the less risky institutions.

The paper most closely related to ours is Lucas et at. (2019), who study how banks' business models adapt to changes in the yield curve when interest rates are low. Using a novel observation-driven finite mixture model, they classify more than 200 European banks into six distinct business model components, providing empirical evidence that banks' business models characteristics evolve over time, adapting to changes in longterm interest rates. Their empirical findings prove that loans-to-assets ratio decreases in response to a drop in long-term rates, and banks' trading and derivative books increase across business models, mostly because of the balance sheet changes by the larger banks. As the authors comment, this result could reflect a decreased demand for new loans from the private sector in an environment of strongly declining rates, which is also in line with Abbassi et al. (2016). In this environment, the authors continue, large banks may invest in tradable securities such as government bonds instead of expanding

$\overline{10}$ See, Altunbas et al. (2011) for a complete discussion of the literature on bank risk and business models. 
their respective loan books. Our empirical evidence expands on these findings, by documenting a substantial portfolio rebalancing towards tradable securities for retail and wholesale banks, which we attribute to regulatory requirements targets (reducing their risk-weighted assets). Moreover, we highlight the compensatory effect played by fees and commissions to contrast the net-interest margin compression induced by the negative interest rate policy. Finally, unlike Lucas et al. (2019), we do find an overall increase of deposits across the business models, thereby suggesting that Italian banks pursued a stabilizing funding policy, to the benefit of systemic financial stability.

To sum up, our analysis connects and expands on the findings we streamlined across the three lines of research, also identifying some specificities of the Italian banking system.

\section{Methodology}

\subsection{Bank business model classification}

As noted by Farné and Vouldis (2017), banks are characterized by varying degrees within a range of activities relative to the composition of their profit earning assets, on the one hand, and their funding sources, on the other. From this viewpoint, balance sheet structures can help identify major business models reflecting risk characteristics (e.g., Altunbas et al. 2011, Ayadi and De Groen 2014), profitability and business activities (e.g., Roengpitya et al. 2014). By and large, the literature on this topic is mainly oriented to process data on balance sheet structure to identify business models, using both data-driven approaches (e.g., cluster analysis or principal component analysis) and expert judgments. The empirical evidence from both approaches mainly lead us to identify three major business models (Ayadi et al. 2011; Roengpitya et al. 2014; Grossmann and Scholz 2018):

- Retail banks: the group is characterized by customer deposits as the primary source of funding and providing predominantly loans (this group is close to the traditional banking model). Ayadi and De Groen (2014) further split retail banks into: (a) focused retail banks, including domestic-oriented ones and part of the cooperative and saving banks; this group provides traditional services such as customer loans and are funded by customer deposits; (b) diversified retail banks, namely, internationally-oriented ones that mostly lend to customers using primarily debt liabilities and customer deposits. Instead, Farné and Vouldis (2017) distinguish between: (a) traditional commercial banks holding more capital and undertaking more credit risk, and (b) complex commercial, banks showing higher market risk exposure than traditional commercial ones.

- Market-oriented banks (or investment banks), which include banks with substantial trading assets active in interbank lending and borrowing. These banks are mostly internationally-oriented and engage extensively in trading activities, while relying on debt securities. ${ }^{11}$ As pointed out by Ayadi and De Groen (2014), since investment

\footnotetext{
11 E.g., in Roengpitya et al. (2014), the average bank in this group has the following asset/liability profile
} (average values of ratios to total assets): loans 25.5 percent; trading assets 51.2 percent; interbank lending 
banks' performance fluctuated substantially during the 2008-2009 financial crisis and the 2010-2012 Eurozone sovereign debt crisis, the group improved their capital position through deleveraging.

- Wholesale banks, characterized by a funding structure less dependent on deposits together with substantial long-term funds. The asset composition is similar to the one of the first group, but the funding mix differs substantially, as the banks of this group typically have a much higher share of wholesale debt. ${ }^{12}$ Compared to retail and capital-oriented banks, they are more cost efficient, with a low cost-to-income ratio (Roengpitya et al. 2014) and more inclined to diversify their incomes (Nucera et al. 2017). Ayadi and De Groen (2014) note that most of the cooperative banks fall within this cluster.

We follow this classification in our empirical analysis. Specifically, we split up our sample based on balance sheet characteristics computed over the years before the negative interest rates (henceforth NIR) as follows:

i. retail banks, including institutions mainly focused on deposits and loans, and specifically showing the average ratio $\frac{\text { TotalDeposits }}{\text { TotalAssets }}>0.50$ together with the average ratio $\frac{\text { Loans }}{\text { TotalAssets }}>0.50$;

ii. market-oriented banks, including all institutions characterized by substantial tradable securities with the average ratio $\frac{\text { Earning Assets }}{\text { TotalAssets }}>0.40 ;{ }^{13}$

iii. wholesale banks, including banks less deposit-dependent, specifically those banks having the average ratio $\frac{\text { TotalDeposits }}{\text { Total Assets }}<0.50$.

Wholesale banks are the "control group", since they are assumed to be less sensitive to negative NIR impacts, being less deposit-oriented and more cost efficient (Roengpitya et al. 2014) as well as more inclined to diversify their incomes (Nucera et al. 2017), while retail and market-oriented banks are our "treated group", for which we aim to assess the differential NIR effects compared to the control group.

\subsection{The empirical model}

To compare the actions of retail and market-oriented banks with those of wholesale banks over time, when policy interest rates have been set by the ECB below zero compared to other years, we perform a 'difference-in-differences' analysis within a panel regression framework. In this way, we isolate the actions taken by the banks within the "treated group", and due to unconventional monetary policy and prudential regulation, from other differences that also exist between bank business models in other years.

The baseline empirical model is provided by the following equation:

Footnote 11 continued

21.8 percent and interbank borrowing 19.1 percent. Deposits are 38 percent, in line with wholesale banks (35.6 percent).

12 Again, using data from Roengpitya et al. (2014), the average bank in this group has (ratios expressed relative to total assets) the following main balance-sheet characteristics: loans 65.2 percent, in line with retail banks (62.2 percent); trading assets 20.7 per cent (retail banks have 22.4 percent); deposits 35.6 percent, substantially lower than retail banks, which exhibit 66.7 percent.

13 Earning Assets are computed as:Total Earning Assets-Loans. 


$$
\begin{aligned}
Y_{i, t}=\alpha & +\beta_{0} \text { Post }_{t}+\sum_{k=1}^{K-1} \beta_{k} \text { Post }_{t} B M_{i, k}+\gamma_{0} \ln \left(\text { TotalAssets }_{i, t}\right) \\
& +\sum_{k=1}^{K-1} \gamma_{k} B M_{i, k} \ln \left(\text { TotalAssets }_{i, t}\right)+\delta_{0}\left(\frac{\text { Equity }_{i, t}}{\text { TotalAssets }_{i, t}}\right) \\
& +\sum_{k=1}^{K-1} \delta_{k} B M_{i, k}\left(\frac{\text { Equity }_{i, t}}{\text { TotalAssets }_{i, t}}\right)+\vartheta_{0} \text { Tier }_{i, t}+\sum_{k=1}^{K-1} \vartheta_{k} B M_{i, k} \operatorname{Tier} 1_{i, t}+\tau_{i}+\varepsilon_{i, t}
\end{aligned}
$$

with $i=1, \ldots, N, k=1, \ldots, K$, and $t=1, \ldots, T$, where $N=125$ is the number of banks, $K=3$ is the number of bank business model with $k=1$ being retail bank group, $k=2$ being the market-oriented bank group and $k=3$ being the control group (wholesale banks), and $t$ is the year from 2011 to 2017. Post $t_{t}$ is a dummy variable that takes the value 1 from 2014 onwards when NIR were set by the ECB and 0 before that period; $B M_{i, k}$ is a dummy variable that takes the value 1 if bank $i$ belongs to the $k-t h$ business model and 0 otherwise. To limit potential bias in coefficient estimates, we include bank fixed effects $\tau_{i}$.

The coefficient of interest is $\beta_{k}$ that represents the average difference in $Y$ between treated (retail and market-oriented banks) and control (wholesale banks) groups. Loans, traded assets, liquid assets, net interest margin, net fees and commissions, and net incomes are, in turn, our dependent variables all expressed as fraction of total assets. We use robust standard errors to control for heteroscedasticity and dependence, with bank-level clustering.

Bank-specific controls are introduced alone and interacted with the business models to capture cross-bank and cross-business models heterogeneity over time:

- The first control is bank size, measured by the logarithm of the $i-t h$ bank total assets at each time $t, \ln \left(\right.$ T otal As set $\left._{i, t}\right)$; asset size is associated with large economies of scale (Mirzaei et al. 2013) and less sensitivity of net interest income to interest risk volatility (Angbazo 1997).

- The second control is the equity-to-assets ratio $\frac{\text { Equity }_{i, t}}{\text { TotalAsset }_{i, t}}$ computed for each bank $i$ at time $t$, which several studies used as a proxy for bank risk aversion (e.g., Saunders and Schumacher 2000; Maudos and de Guevara 2004) and as a determinant of credit supply by banks (Gambacorta and Shin 2018; Michelangeli and Sette 2016).

- The third control is the Tier 1 capital ratio, which we use as proxy for bank riskbearing capacity and is extensively used in the literature to study how capital requirements affect lending behavior (e.g., Gambacorta and Mistrulli 2004; Aiyar et al. 2014; Fraisse et al. 2019). In our empirical analysis, the Tier 1 capital ratio helps quantify the role played by the regulation, thereby disentangling the impact

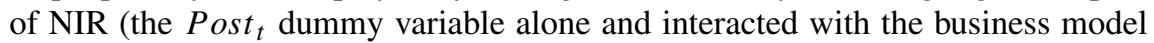
connotation) and Basel III on bank profitability and portfolio rebalancing.

Because of potential reverse causation between dependent variable(s) and covariates, Eq. (1) is extended by including instrumental variables $Z_{i, t}$ in order to isolate 
the covariates variability, which is uncorrelated with the error terms. The instruments used in the panel regressions are the three bank-specific controls alone and interacted with the business models lagged one year, when the dependent variable is loans, earning and liquid assets; when the dependent variables consist in bank margins, we also include loans over total assets alone and interacted with the business models lagged one year, the reverse causality between loans and bank margins (net interest margin, commission and fees margin) being substantial. Instrument exogeneity condition is tested through the Sargan's over-identification test.

\section{Bank business models before and after June 2014}

\subsection{Dataset}

The dataset comes from Orbis (Bureau van Dijk) and refers to annual bank balance sheets of 125 active Italian banks over the period from 2011 to 2017 with no missing values. The sample includes all legal forms admitted in Italy (public limited banks, cooperative banks, and 'popolari' banks), accounting for around 83 per cent of the total assets of all banks operating in Italy over the period 2011-2017. Table 2 reports preliminary descriptive statistics of the sample, which we split based on banks' legal form (see Appendix A for the complete list of all 125 banks in the sample). As discussed, since we cover small to systemically important institutions, our sample closely matches the characteristics of the entire banking population in Italy over the years 2011-2017.

We classify bank business models based on balance sheet characteristics computed over the years 2011-2013 (pre-NIR); see Sect. 3. The sample of 125 banks is thus split up in 3 groups, namely (i) retail banks (48); (ii) market-oriented banks (29); and (iii) wholesale banks (48). Table 2 reports average values of bank balance sheet variables

Table 2 Descriptive statistics: Average values over the period 2011-2017

\begin{tabular}{lllllll}
\hline & $\begin{array}{l}\text { Number (as of } \\
\text { 2017) }\end{array}$ & \multicolumn{2}{l}{ Assets (mln $€$ ) } & & & \\
\cline { 3 - 6 } & & Total & $\%$ & Min & Mean & Max \\
\hline Cooperative banks & 28 & 111,127 & 3.374 & 253 & 3,502 & 49,622 \\
'Popolari' banks & 19 & 105,099 & 3.191 & 72 & 5,396 & 41,625 \\
Public limited banks & 78 & $3,077,719$ & 93.436 & 28 & 39,918 & 926,827 \\
Total & $\mathbf{1 2 5}$ & $\mathbf{3 , 2 9 3 , 9 4 5}$ & & & & \\
Italian banking system & & $\mathbf{3 , 9 7 8 , 7 7}$ & $\mathbf{8 2 . 7 8 8}{ }^{\dagger}$ & & &
\end{tabular}

Note: Descriptive statistics of the sample. Values and percentages are computed as average over the period 2011-2017. The total assets for "Italian banking system" come from 'Banks and Money: National Data', Banca d'Italia, Statistics Series (https://www.bancaditalia.it/pubblicazioni/moneta-banche/2018-moneta/ index.html)

Computed as total assets of our sample over total assets of the Italian banking system 
before (2011-2013) and after (2014-2017) NIR policy for assets and liabilities (Panel A) and bank's profitability (Panel B). Table 3 reports the first differences between the two sub-periods with corresponding $t$-stat. Over the period 2011-2013, average values of bank characteristics reflect, obviously, the approach we use to classify banks within the 3 clusters. As a result, retail and wholesale banks show higher ratios for loans, ${ }^{14}$ while market-oriented banks denote higher trading and liquid assets (see Appendix B for a complete description of the balance sheet variables). On the liability side, retail deposits are the main funding channel for retail banks (58.51 percent on average), while wholesale banks are more dependent on market-based funding, with long term plus interbank funding around 48 percent, versus 37 percent of retail deposits; marketoriented banks denote a substantial equally-weighted funding structure with long term and interbank funding around 38 percent and retail deposits around 40 percent. Again, this group appears to be better capitalized (equity is about 11 percent of total assets), exhibiting higher capital adequacy (Tier 1 is close to 26 percent on average), with lower risk weighted assets (RWA), which is close to 40 percent of total assets.

Bank's profitability is under pressure for wholesale banks, with an average ROA slightly under zero ( -0.05 percent); instead, retail and market-oriented banks show slightly positive ROAs ( 0.195 and 0.23 per cent, respectively). Net Interest Incomes (NII) and Net Fees and Commissions (NFC) are the major contributors to Operating Income (OI); together, they account for about 90 percent for all groups.

Balance sheet structures change substantially over the sub-period 2014-2017. Tables 3 and 4 denote significant changes that occurred between pre- and post-NIR. Loans decreased and trading assets increased for retail and wholesale banks, while liquid assets expanded substantially only for retail banks (the variation for wholesale banks, while positive, is not statistically significant). All groups largely increased deposits at the expense of long-term funding, thus shortening liability duration. Therefore, we might conjecture that a bank's income gap, which measures the difference between rate sensitive assets and rate sensitive liabilities (Mishkin and Eakins 2009), increased, thereby reflecting on higher sensitivity of bank's profitability to interest rate changes. ${ }^{15}$ This is indeed what we observe for NII, which shows a significant negative variation for all groups. Such NII compression is partially alleviated by NFC only for retail and wholesale banks, although variations are not statistically significant. Hence, wholesale bank's profitability is even more under pressure over the sub-period 2014-2017 with a ROA reaching - 0.53 percent, and then exhibiting a significant negative change from pre- to post-NIR. Again, in the post-NIR period the contribution of NII and NCF to OI tightens significantly, which suggests that banks realized higher net trading incomes together with dividends and other incomes from equity investments. ${ }^{16}$

From 2011-2013 to 2014-2017, the Italian banking system became less exposed to risk, with a significant reduction in risk-weighted assets (RWA), in particular for retail

\footnotetext{
14 All balance sheet items are expressed as ratio over total assets.

15 The income gap measures the extent to which a bank's net interest income is sensitive to changes in interest rates. In fact, the common approach used in the literature (Gomez et al. 2020) to assess the impact of a potential change in short rates $\Delta r$ on bank's income is: Income Gap $\times \Delta r$.

16 Together with NII and NCF, Operating Income includes: Net trading incomes and dividends and other incomes from equity investments.
} 


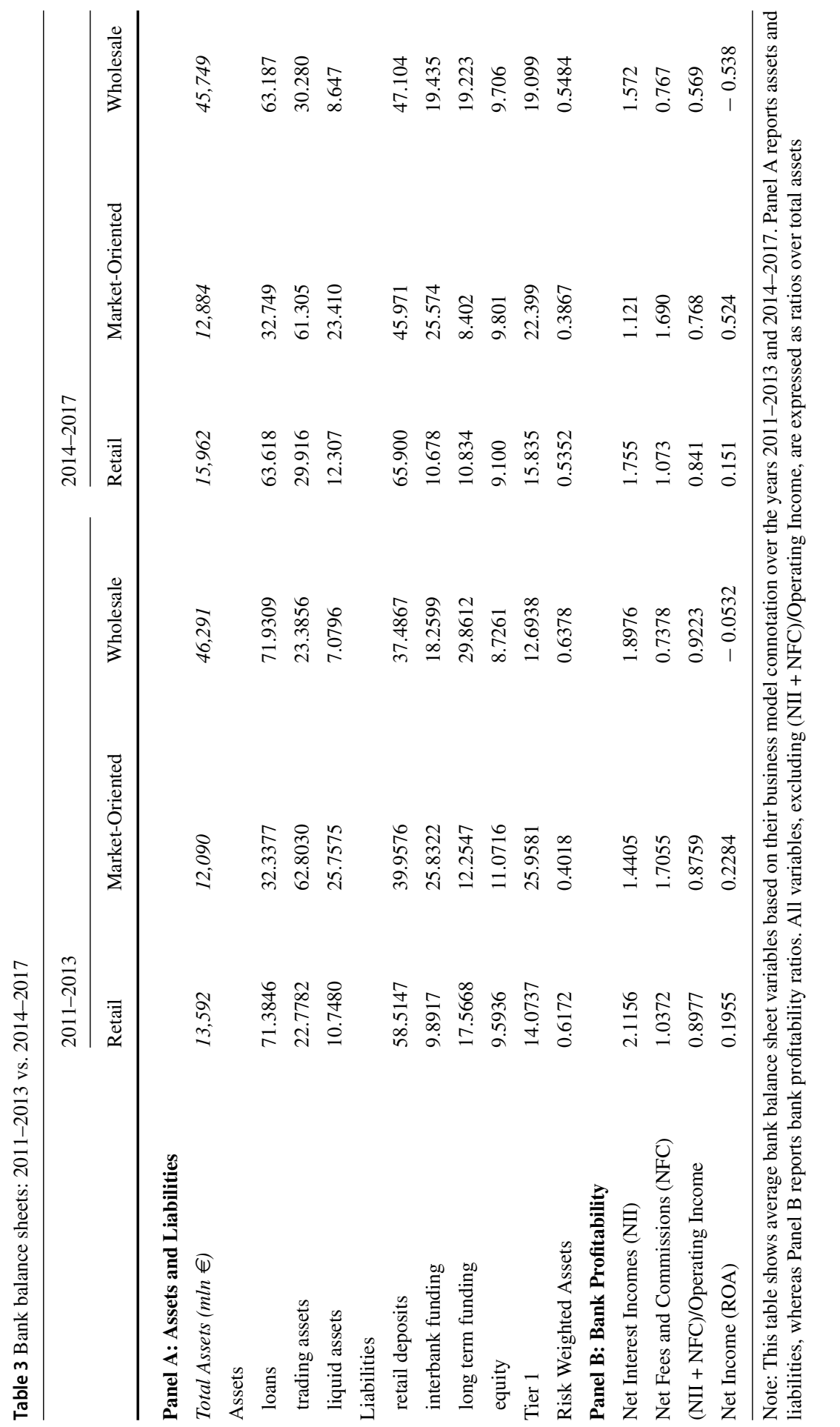




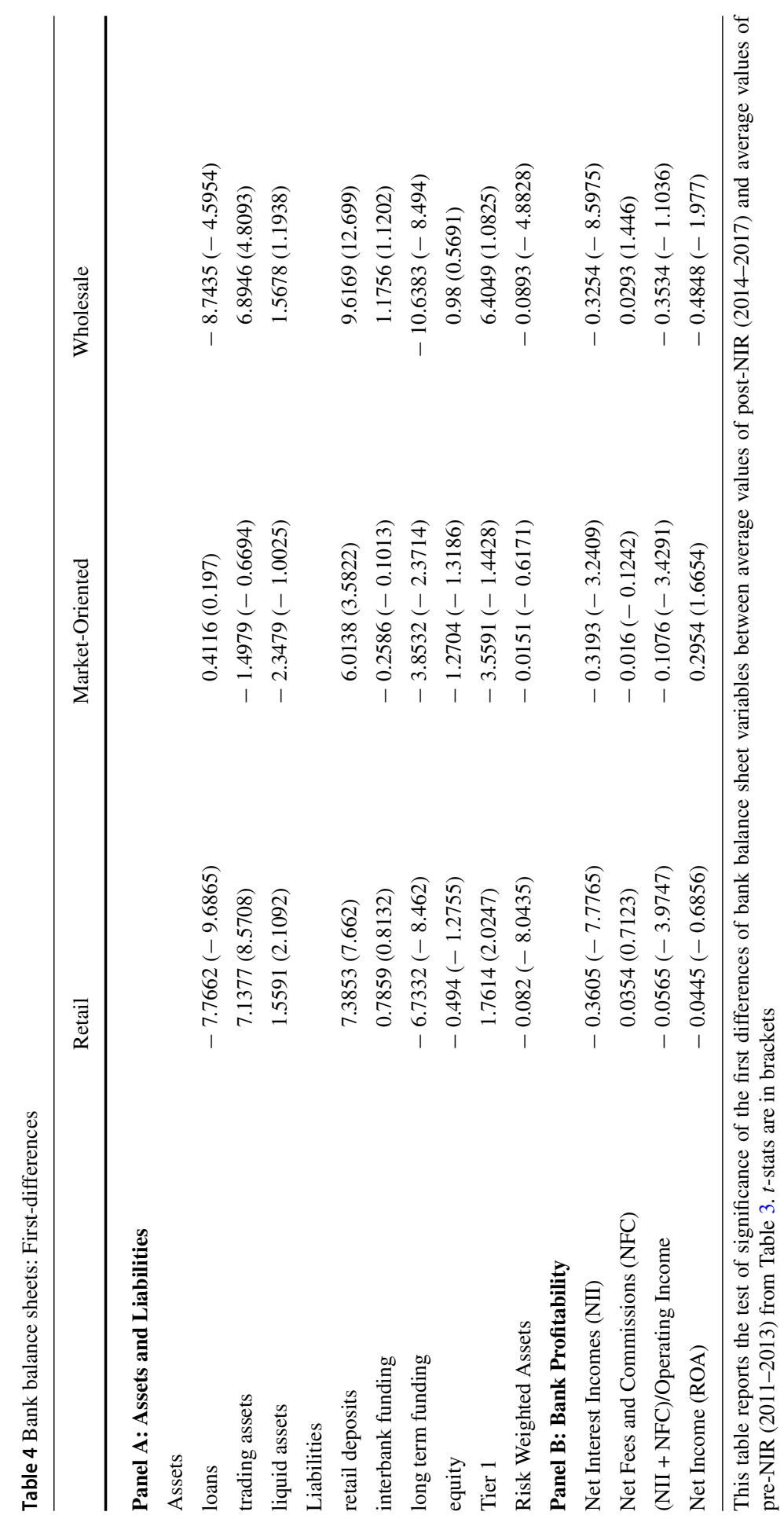


and wholesale banks, and more financially resilient, as documented by the average Tier 1 ratio, whose values range between 15.84 to 22.40 percent in post-NIR with significant incremental changes for retail and wholesale banks; market-oriented banks show a slightly reduction in Tier 1 ratio, while remaining at a higher level (on average, it is slightly higher than 22 percent).

\subsection{How bank business models changed with negative rates and the new prudential regulation}

Descriptive statistics commented in the previous section provide preliminary evidence of the substantial changes in bank balance sheets from 2011-2013 to 2014-2017. How and why did bank business models change between the two sub-periods? Answering this question also helps us understand what might have been the strategic model assumed by banks when policy rates turned negative and capital and liquidity regulation came into effect. To do this, we focus on changes occurred in bank business models, re-assigning each institution within the three clusters using the average values of balance sheet variables over the period 2014-2017. The double-entry Table 5 , reporting all migrations occurred from pre- to post-NIR for each group of banks, denotes a clear polarization towards retail- and market-oriented banks in the years 2014-2017. Our evidence is in line with Roengpitya et al. (2014), who find that retail banking and, with minor emphasis, trading banks, have gained popularity in the postcrisis scenario, because of a more stable performance. Nearly two-thirds of wholesale banks switched to retail-banks, while market-oriented banks are stable within their cluster. As a result, in the post-NIR retail banks account for less than two-thirds of the total sample (77/125), market-oriented for more than a quarter (35/125), and wholesale banks for about 10 percent (13/125).

As is clear, the major structural change regards wholesale banks, which moved massively towards retail banking (see Table 5). To explore the propensity of banks to shift into retail-bank business model in the post-NIR, we estimate the following Probit model:

$$
p_{i, t}=\operatorname{Pr}\left(D_{i, t}=1 \mid \bar{X}_{i, \tau}\right)=\phi\left(\bar{X}_{i, \tau}^{\prime} b\right)
$$

Table 5 Bank business model transitions

2014-2017

Total

2011-2013

Retail

Market-Oriented

Wholesale

\begin{tabular}{lcccc}
\hline Retail & 43 & 3 & 2 & 48 \\
Market-Oriented & 3 & 24 & 2 & 29 \\
Wholesale & 31 & 8 & 9 & 48 \\
Total & 77 & 35 & 13 & $\mathbf{1 2 5}$ \\
\hline
\end{tabular}

The table reports bank business model transitions occurred from the years 2011-2013 to 2014-2017 
where $D_{i, t}$ is a dummy variable denoting the transition for the bank $i$ from non-retail bank business model (i.e., wholesale or market-oriented banks) in the pre-NIR subperiod $\tau$ (2011-2013) to retail-banking in the post-NIR sub-period $t$ (2014-2017). The dummy takes the value of 1 if this shift occurred, and 0 otherwise. $\bar{X}_{i, \tau}$ is the transposed vector of bank characteristics in the pre-NIR sub-period, $b$ is the vector of coefficient estimates, and $\phi$ is a standard normal cumulative distribution function. To choose the covariates $X$, we mostly rely on the main balance sheet items that characterize banks in terms of business model connotation, risk-weighted assets, and leverage. Hence, we select loans-to-assets (L/TA), earning-to-assets (S/TA), RWAto-assets (RWA/TA), and equity-to-assets ratios (E/TA). The results of the model's estimation are presented in Table 6. Except for securities, the covariates are significant at 1-to-5 per cent level, suggesting that banks shifting into retail-bank business model did so because of the level of loans as well as the riskiness of their assets and connected capital adequacy. In more depth, banks whose lending activity is relatively low (L/TA coefficient is negative), risk-weighted assets tend to be higher (RWA/TA coefficient is positive) and equity is low (E/TA coefficient is negative), thus reflecting higher risk aversion (Saunders and Schumacher 2000; Maudos and de Guevara 2004), are more

Table 6 Propensity to shift into retail-bank business model in the post-NIR

\begin{tabular}{ll}
\hline & Coefficient \\
\hline Constant $\left(b_{o}\right)$ & -1.2364 \\
$R W A / T A\left(b_{1}\right)$ & $(0.7762)$ \\
& $2.1532^{* *}$ \\
$E / T A\left(b_{2}\right)$ & $(1.0363)$ \\
& $-0.0583^{* *}$ \\
$L / T A\left(b_{3}\right)$ & $(0.0291)$ \\
& $-0.0554 * * *$ \\
& $(0.0187)$ \\
McFadden $\left(b_{4}\right)$ & 0.011 \\
Log likelihood & $(0.0091)$ \\
Log likelihood ratio statistic & 0.097247 \\
\hline
\end{tabular}

The table reports estimate of the following Probit model: $p_{i, t}=\operatorname{Pr}\left(D_{i, t}=1 \mid \bar{X}_{i, \tau}\right)=$

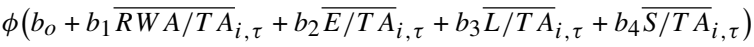

where $D_{i, t}$ is a dummy variable denoting the transition for the bank $i$ from non-retail bank business model (wholesale or market-oriented banks) in the pre-NIR sub-period $\tau$ (2011-2013) to retail-banking in the post-NIR sub-period $t$ (2014-2017). The dummy takes the value of 1 if this shift occurred, and 0 otherwise. $\overline{R W A / T A}$ is the average risk-weighted assets over total assets ratio in the pre-NIR sub-period, $\overline{E / T A}$ is the average equity-to-assets ratio in the pre-NIR sub-period, $\overline{L / T A}$ is the average loans-to-assets ratio in the pre-NIR sub-period, $\overline{S / T A}$ is the average earning-to-assets ratio in the pre-NIR sub-period. Standard errors are in brackets. $* * *, * *$, denote statistical significance at $0.001,0.05$, and 0.1 level. 
inclined to change their business model. Note the higher magnitude of the RWA/TA coefficient compared to other covariates. As the ratio is linked to Tier 1, and then to the proxy we use to measure the impact played by the new prudential regulation, our results also suggest the primary role played by Basel III in moving banks toward retail-based business model. Incidentally, the point suggests also that the increase of deposits occurred as whole from pre- to post-NIR may well be ascribed to Basel III, rather than the low-rate environment.

This preliminary evidence is important as it confirms the insights from Table 5 on the major changes occurred from pre- to post-NIR in the balance sheet structure of Italian banks. Indeed, the substantial and significant reduction of risk-weighted assets and the higher financial resilience in terms of capital adequacy (equity and Tier 1 ratios) were the major effects of the substantial portfolio rebalancing occurred over the period 2014-2017.

Now we move onto a deeper empirical investigation about the impact of negative policy rates, and the new regulatory framework introduced with Basel III, on lending, portfolio rebalancing, and profitability of Italian banks.

\section{Empirical results}

We present our results in two steps. First, we document the effect of NIR on bank lending $L$, and structural changes in assets composition, specifically on investments in trading assets (earning assets) $S$, and liquid assets $L I Q$. Second, we measure the impact on bank profitability, by focusing on net-interest margin NII, net fees and commissions $N F C$, and return on assets (net income over total assets) ROA. In both steps, we check the consistency of our model specification by contrasting our results with those obtained from random-effects panel models and choose the more appropriate specification using the Hausman test.

Consider, first, the behavior of the key variables, which we fully scrutinize within our econometric framework in the next sections, for the treated and the control groups before and after the cut-off date 2014. Figure 1 displays the average values computed for banks belonging to the treated groups (retail and market-oriented banks) and the control group (wholesale banks) for loans-to-asset ratio, earning-to-assets ratio, and liquid-to-assets ratio. Note that retail and wholesale banks have the same trend for lending and securities (loans decrease and trading assets increase after the cut-off year 2014), while liquid assets exhibit three different patterns, in which wholesale banks have the higher level, followed by retail- and market-oriented banks. The same Fig. 1 depicts the trends for net-interest margin, net fees and commissions, and ROA (net income over total assets). The compression of net-interest margin is common among the three groups, while fees and commissions have different tendencies, with marketoriented banks showing the highest values, followed by retail and wholesale banks. Interestingly, the return on assets turned to be negative for the control group, while the trend is positive and increasing for market-oriented banks; retail banks exhibit positive values before and after the cut-off, with a slight compression in 2013, when the average bank in the group has a $R O A$ quite close to zero. 

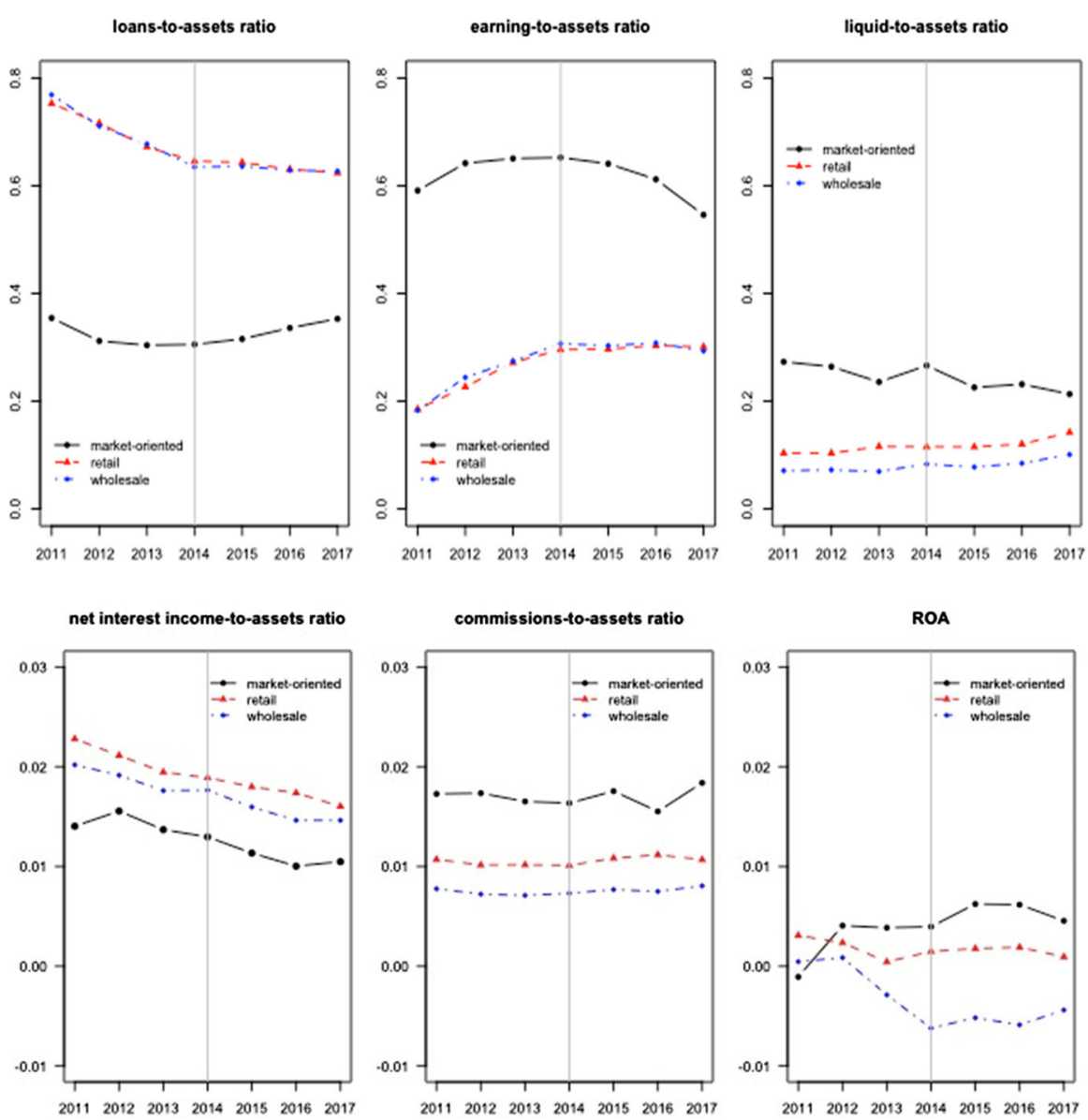

Fig. 1 Bank business models: Key variables over the period 2011-2017. Note: The figure displays the trend over the period 2011-2017 for the average values of banks belonging to the treated group (retail- and market-oriented banks) and the control group (wholesale banks) of the following ratios: loans-to-assets, earning-to-assets, liquid-to-assets, net-interest income-to-assets, commissions-to-assets, ROA. Vertical grey line denotes the cut-off date 2014, when negative policy rate was set by the ECB

\subsection{Lending under negative policy interest rates}

Table 7 reports regression results for the loans-to-assets ratio, L/TA. The effects of NIR on market-oriented banks are significantly different from the control group, while retail banks do not react differently compared to wholesale banks. The differential effects of the unconventional monetary policy are depending on the business model connotation, whose interactions with bank-specific controls are significant for the equity-to-assets ratio and the Tier 1 ratio, while bank size $\left(\ln \left(\right.\right.$ Total Asset $\left.\left._{i, t}\right)\right)$ does not exert a significant impact on loans, when interacted with the business model. Unlike retail and wholesale banks, both of which have reduced credit to the economy after 
Table 7 Impact on loans, securities and liquid assets

\begin{tabular}{|c|c|c|c|}
\hline & $\mathrm{L} / \mathrm{TA}$ & S/TA & LIQ/TA \\
\hline \multirow[t]{2}{*}{ Post $\left(\beta_{0}\right)$} & $-0.0474 * * *$ & $0.0306 * * *$ & $0.0068^{*}$ \\
\hline & $(0.0082)$ & $(0.0082)$ & $(0.0041)$ \\
\hline \multirow[t]{2}{*}{ Post_R $\left(\beta_{1}\right)$} & 0.0163 & -0.0084 & -0.0104 \\
\hline & $(0.0128)$ & $(0.0127)$ & $(0.0098)$ \\
\hline \multirow[t]{2}{*}{ Post_M $\left(\beta_{2}\right)$} & $0.0754 * * *$ & $-0.0754 * * *$ & -0.0314 \\
\hline & $(0.0152)$ & $(0.0175)$ & $(0.0224)$ \\
\hline \multirow[t]{2}{*}{$\operatorname{size}\left(\gamma_{0}\right)$} & -0.0488 & $0.0765^{* *}$ & 0.0088 \\
\hline & $(0.0334)$ & $(0.0371)$ & $(0.0128)$ \\
\hline \multirow[t]{2}{*}{ size_R $\left(\gamma_{1}\right)$} & -0.0778 & 0.0542 & 0.0671 \\
\hline & $(0.0571)$ & $(0.0569)$ & $(0.0647)$ \\
\hline \multirow[t]{2}{*}{ size_M $\left(\gamma_{2}\right)$} & -0.0105 & -0.0152 & 0.0425 \\
\hline & $(0.0657)$ & $(0.0654)$ & $(0.1007)$ \\
\hline \multirow[t]{2}{*}{ equity $\left(\delta_{0}\right)$} & $-0.8482 * *$ & $0.6448 * *$ & $0.6414 * * *$ \\
\hline & $(0.3288)$ & $(0.2879)$ & $(0.0733)$ \\
\hline \multirow[t]{2}{*}{ equity_R $\left(\delta_{1}\right)$} & 1.2534 & -1.2142 & $-0.9821 *$ \\
\hline & $(0.8367)$ & $(0.7596)$ & $(0.5392)$ \\
\hline \multirow[t]{2}{*}{ equity_M $\left(\delta_{2}\right)$} & $1.6885^{*}$ & $-1.7319^{*}$ & -0.4301 \\
\hline & $(0.8752)$ & $(0.9445)$ & $(0.6715)$ \\
\hline \multirow[t]{2}{*}{$\operatorname{Tier} 1\left(\vartheta_{0}\right)$} & -0.0008 & 0.0007 & $0.0003^{* *}$ \\
\hline & $(0.0007)$ & $(0.0005)$ & $(0.0001)$ \\
\hline \multirow[t]{2}{*}{ Tier1_R $\left(\vartheta_{1}\right)$} & $-0.0048^{*}$ & $0.0047 * *$ & $0.0035^{* *}$ \\
\hline & $(0.0025)$ & $(0.0022)$ & $(0.0016)$ \\
\hline \multirow[t]{2}{*}{ Tier1_M $\left(\vartheta_{2}\right)$} & -0.0023 & 0.002 & -0.0002 \\
\hline & $(0.0018)$ & $(0.0019)$ & $(0.0016)$ \\
\hline Sargan test & $1.862(0.785)$ & $0.184(0.844)$ & $0.492(0.781$ \\
\hline Hausman test & $104.13 * * *$ & $49.968 * * *$ & $23.468 * *$ \\
\hline $\mathrm{FE} / \mathrm{RE}$ & FE & $\mathrm{FE}$ & $\mathrm{FE}$ \\
\hline Adj. R-squared & 0.3955 & 0.159 & 0.0201 \\
\hline$\beta_{0}+\beta_{2}$ & $2.1929 * *$ & $-2.8955^{* * *}$ & - \\
\hline
\end{tabular}

Note: This table estimates $Y_{i, t}=\alpha+\beta_{0}$ Post $_{t}+\sum_{k=1}^{K-1} \beta_{k}$ Post $_{t}$ BM $_{i, k}+\gamma_{0} \ln \left(\right.$ TotalAssets $\left._{i, t}\right)+$ $\sum_{k=1}^{K-1} \gamma_{k} B M_{i, k} \ln \left(\right.$ TotalAsset $\left._{i, t}\right)+\delta_{0}\left(\frac{\text { Equity }_{i, t}}{\text { TotalAssets }_{i, t}}\right)+\sum_{k=1}^{K-1} \delta_{k} B M_{i, k}\left(\frac{\text { Equity }_{i, t}}{\text { TotalAssets }_{i, t}}\right)+\vartheta_{0}{\text { Tier } 1_{i, t}}+$ $\sum_{k=1}^{K-1} \vartheta_{k} B M_{i, k}$ Tier $1_{i, t}+\tau_{i}+\varepsilon_{i, t}$

$Y_{i, t}$ is loans-to-assets ratio (column L/TA), earning-to-assets ratio (column S/TA), and liquid assets over total assets ratio (LIQ/TA) for bank $i$ at time $t . K=3$ is the number of bank business model with $k=1$ being retail bank group, $k=2$ being the market-oriented bank group and $k=3$ being the control group (wholesale banks). Post $_{t}$ is the dummy variable that takes the value 1 from 2014 onward and 0 before that period; $B M_{i, k}$ is a dummy variable that takes the value 1 if bank $i$ belongs to the $k-t h$ business model and 0 otherwise; $\tau_{i}$ is the bank fixed effects. Robust standard errors with bank-level clustering are in brackets. The table reports also the Sargan over-identification test (with $p$-value in brackets) and the Hausman test. $\beta_{0}+\beta_{2}$ is the $t$-test on the sum of the two coefficients. FE/RE indicates whether the panel model is estimated with fixed effects (FE) or random effects (RE) $* * *, * *, *$ denote statistical significance at $0.001,0.05$, and 0.1 level 
the introduction of NIR policy, the unconventional monetary policy has produced an expansive effect on the amount of loans granted by market-oriented banks.

The coefficient $\beta_{0}$ is -0.0474 , thus indicating a credit contraction induced by NIR policy for wholesale banks, while $\beta_{2}$, representing the average differential impact on loans of market-oriented banks compared to the control group (wholesale banks), is 0.0754. The combined effect of $\beta_{0}+\beta_{2}$ (see Table 7) suggests that the effect of NIR policy on loans has been significantly positive for market-oriented banks, though the negative impact on loans is ascribed to the control group (the $t$-stat is 2.1929). On the other hand, the average differential impact on retail banks has been negligible, as the coefficient $\beta_{1}$ is not statistically significant.

Equity-to-assets and Tier 1 ratios significantly affect the loan dynamics conditionally to the bank business model. $\delta_{0}$, which measures the average impact on loans induced by the equity-to-assets ratio for the control group, is -0.8482 , thereby indicating a negative relationship between bank equity and lending. Instead, the impact for market-oriented banks is positive, with $\delta_{2}=1.6885$. According to the bank lending channel arguments (e.g., Bernanke and Blinder 1988; 1992), financially constrained banks are expected to show stronger reactions to monetary policy interventions (Kashyap and Stein 2000; Jiménez et al. 2012; Altavilla et al. 2019). Instead, larger capital reduces the financing constraint faced by banks, leading them to grant more loans to the economy. Our results are consistent with this view, as market-oriented banks expanded the credit supply, being less financially constrained, while wholesale banks, being more financially constrained, reduced loans to the economy. Moreover, the new banking regulatory framework introduced with the Single Supervisory Mechanism (SSM), for which the ECB is responsible for direct supervision over the so-called "significant important financial institutions" (SIFI), could have an impact as well. In particular, recent evidence has proven how centralization of banking supervision reduced lending for banks within the SSM list in euro stressed-countries. ${ }^{17}$ Indeed, we find all the significant Italian institutions as of 2014, when the centralized supervision became operational, within the wholesale banks group.

The loan sensitivity to the Tier 1 ratio for retail banks is negative, suggesting that this group moved towards better regulatory capital adequacy by reducing lending. The average values of the Tier 1 ratio before the introduction of NIR for the three bank business models (see Table 3 ) confirms this finding, as they denote higher capital adequacy for market-oriented banks, with an average Tier 1 ratio around 26.25 percent, while retail and wholesale banks exhibit values around 13.94 and 12.67 percent, respectively. These two groups substantially increased their Tier 1 ratios over the postNIR period, with values around 15.83 percent, for retail banks, and 19.12 percent, for wholesale banks. Market-oriented banks slightly lowered the ratio to 22.39 percent, while nevertheless maintaining a strong capital adequacy. These numbers corroborate a balance sheet rebalancing for retail and wholesale banks according to a portfolio strategy aiming at increasing their capital adequacy by reducing their exposures to high-risk asset classes, i.e. loans, while elevating their own funds through capital injections, i.e. equity. This is the reason why $\delta_{0}$ is negative, as it denotes a negative

\footnotetext{
17 Altavilla et al. (2019) prove that centralization of supervision at the ECB reduced the overall lending to riskier borrowers in stressed-countries, thereby offsetting the bank risk-taking stimulated by monetary policy easing.
} 
impact on lending when equity-to-assets ratio tends to increase for the control group. The same conclusion holds good for retail banks, for which an increase in Tier 1 ratio reflects on less lending.

Market-oriented banks did not pursue such a balance sheet rebalancing, as they increased their lending activity thanks to higher capital, thereby slightly reducing their Tier 1 ratio in the post-NIR period.

The bank size control variable does not matter for any of the bank groups. This result contrasts with the credit channel arguments on the role of bank size and monetary policy sensitivity. The common view (e.g. Kashyap and Stein 1995, 2000; Kishan and Opiela 2000) is that loan growth in the smaller banks is more sensitive to monetary policy as they may not be able to bypass a deposit shock and preserve lending by raising new funds. On the other hand, large banks should be less prone to reducing lending in the event of a crisis (Gambacorta and Marques-Ibanez 2011; Jiménez et al. 2014; Popov and van Horen 2013) because of greater diversification possibilities. Instead, our findings provide a different view, since bank size does not help explain the lending dynamics before and after NIR. Rather, our evidence seems in line with studies pointing to the business model of smaller banks, which, being mostly based on the relationship-banking paradigm, leads low-tier size banks to be less inclined to shrink their credit portfolio than larger banks in crisis periods (Petersen and Rajan 1994; Berger and Udell 1995).

\subsection{Securities and liquid assets rebalancing}

Securities and liquid assets are the other two main asset classes of the balance sheet that banks manage depending on their liability structure, which includes deposits, shortand long-term funding, and equity. In this section, we explore the effects of negative interest rates on securities and liquid assets using the same econometric specification of Eq. (1), while using as dependent variable the earning-to-assets ratio S/TA, and the liquid-to-assets ratio ${ }^{18} \mathrm{LIQ} / \mathrm{TA}$.

\subsubsection{Securities}

Results for earning-to-assets ratio in Table 7 denote, first, a positive coefficient estimate for $\beta_{0}$ of 0.0306 , indicating an increase in security investments for wholesale banks when the NIR policy became operational. The average differential impact on earningto-assets ratio for market-oriented banks, compared to the control group (wholesale banks), is instead the opposite as the coefficient estimate $\beta_{2}$ is -0.0754 , thereby indicating a shrinkage on security investments for this group. The combined effect of $\beta_{0}+\beta_{2}$ (see Table 7) (the $t$-stat is -2.8955 ) confirms the negative impact on security investments for market-oriented banks, though the impact has been positive for wholesale banks. As for loans, the average differential impact on securities for retail banks has been negligible, since the coefficient $\beta_{1}$ is not statistically significant. Taken together,

\footnotetext{
18 Liquid assets (the numerator) include cash due from banks, trading securities and at fair value through income, loans and advances to banks, reverse repos and cash collaterals.
} 
results on lending activity and security investments indicate different portfolio rebalancing depending on bank business model. The effect of the unconventional monetary policy of the ECB is expansive on loans for market-oriented banks at the expense of other earning assets (securities), while negative interest rates lead wholesale banks to less lending and more security investments. Such a different portfolio rebalancing is strengthened by bank size and equity. More in detail, since wholesale banks exhibit a positive coefficient estimate for $\ln \left(\right.$ Total As set $\left._{i, t}\right)$, with $\gamma_{0}=0.0765$, and for equity-to-assets ratio, with $\delta_{0}=0.6448$, we confirm previous findings on portfolio rebalancing. Furthermore, for retail banks we reinforce our evidence on the balance sheet rebalancing for regulatory capital adequacy reasons, inferred by exploring the lending dynamics. The average differential sensitivity to the Tier 1 ratio is positive $\left(\vartheta_{1}=0.0047\right)$, while the sensitivity towards loans is negative (see previous section). This suggests that this group moved towards better regulatory capital adequacy by reducing lending and increasing securities, which are less risk-absorbing compared to loans.

Likewise, market-oriented banks denote a negative coefficient estimate for the equity-to-assets ratio interacted with the business model dummy $\left(\delta_{2}=-1.7319\right)$, indicating less investments in securities. This is consistent with previous results on the relationship between credit supply and equity-to-assets ratio. In fact, being less financially constrained, as denoted by the high value of the ratio of market-oriented banks, reflects, on the one hand, on more lending, and on the other on less security investments.

\subsubsection{Liquid assets}

The portfolio rebalancing connected to unconventional monetary policy also impacted on liquid assets dynamics. Regression results in Table 7 document that wholesale banks significantly increased liquid assets following the introduction of negative interest rates, as shown by the corresponding coefficient estimate $\left(\beta_{0}=0.0068\right)$. No significant changes connected to NIR policy, instead, result for retail and market-oriented banks. The equity-to-assets ratio of the control group, while being connected with lending curtailment, is positively related to liquid assets $\left(\delta_{0}=0.6414\right)$. The relationship is instead overturned for retail banks, which exhibit a negative differential impact on liquid assets $\left(\delta_{1}=-0.9821\right)$, compared to wholesale banks. To better understand this finding, let us consider, first, that both groups significantly increased liquid assets from pre- to post-NIR (see Table 3). This is probably attributable to the regulatory framework introduced with Basel III designed to limit funding risk arising from maturity mismatches between bank assets and liabilities. This was not the case for market-oriented banks, whose liquid assets were already adequate over the period 2011-2013: on average, liquid-to-assets ratio for the group was 25.76 percent, versus 10.75 and 7.08 percent for retail and wholesale banks, respectively. Therefore, retail and wholesale banks seem to have implemented a portfolio strategy devoted to reinforcing capital and liquidity requirements. In terms of differential effects, wholesale banks exhibit a stronger effect compared to retail banks (thereby explaining the negative coefficient $\delta_{1}$ ). However, the sensitivity to Tier 1 ratio, while modest in magnitude, 
is positive for both groups $\left(\vartheta_{0}=0.003\right.$ and $\left.\vartheta_{1}=0.0035\right)$ and confirms our hypothesis, also suggesting that the two groups engaged in a strategy of reinforcing stable sources of funding and reducing assets requiring funding. Such evidence coincides with King (2013), who proves that banks below the liquidity requirement needing to be compliant with Basel III requirements increase holdings of higher-rated securities. Having documented the significant portfolio rebalancing for wholesale banks and retail banks, now the question is how these different portfolio rebalancing strategies reflected on bank profitability. This is what we inspect in the next section.

\subsection{Bank profitability}

When interest rates become negative, banks are reluctant to pass negative rates onto depositors, which increases the funding cost of high deposit banks, so the yield curve flattens and compresses interest income on long-term maturity assets. Both effects have an impact on bank profitability that can vary according to bank and country-specific characteristics (Molyneux et al. 2019).

Bernanke (2016) argues that modestly negative short-term rates should not have large effects on profitability for wholesale banks, while those institutions that rely primarily on retail deposits would likely suffer larger margin compression. The effect of NIR on bank profitability also depends on banks' ability to diversify their incomes, in particular by raising fees and commissions.

We test the impact of NIR policy on net interest income, net fees and commissions, and net income using Eq. (1). As discussed in the methodological section, together with the three instruments (size, equity-to-total assets and Tier 1 ratio), we also include loans-to-assets ratio (alone and interacted with the business models lagged one year), in order to control for reverse causality between loans and bank margins.

\subsubsection{Net interest income}

Table 8 reports results on net interest income-to-assets. The coefficients $\beta_{0}$ and $\beta_{2}$ are both negative ( -0.0016 and -0.0015 , respectively) indicating that the impact of NIR policy on net interest margin has been negative for wholesale banks $\left(\beta_{0}\right)$ and market-oriented banks $\left(\beta_{2}\right)$, which show a negative differential impact compared to the control group. No statistical evidence appears for retail banks. This finding seems to contrast with what we should expect in a negative interest rate environment. In fact, since negative interest rates are passed-through to bank deposit rates only in part (e.g., Lopez et al. 2018), when lending rates are moving closer to policy rates, high deposit banks should suffer most for margin compression (Heider et al. 2019). Instead, our evidence says something different for the Italian banking system, since banks relying primarily on retail deposits were not experienced a margin compression such as the one that occurred to wholesale and market-oriented banks, which are both less dependent on retail deposits. The combined effects of $\beta_{0}+\beta_{1}+\beta_{2}$ are statistically different from zero (the $t$-stat is -3.5181 ), confirming that interest rate income compression induced by NIR policy has been substantial for the Italian banking system as a whole, although retail banks seem not to have suffered from the same 
Table 8 Impact on bank profitability

\begin{tabular}{|c|c|c|c|}
\hline & NII/TA & NFC/TA & ROA \\
\hline Post $\left(\beta_{0}\right)$ & $\begin{array}{l}-0.0016^{* * *} \\
(0.0004)\end{array}$ & $\begin{array}{l}0.0008 * * * \\
(0.0002)\end{array}$ & $\begin{array}{l}-0.0016 \\
(0.0015)\end{array}$ \\
\hline Post_R $\left(\beta_{1}\right)$ & $\begin{array}{l}0.0006 \\
(0.0006)\end{array}$ & $\begin{array}{l}0.0004 \\
(0.0005)\end{array}$ & $\begin{array}{l}0.0032 \\
(0.002)\end{array}$ \\
\hline Post_M $\left(\beta_{2}\right)$ & $\begin{array}{l}-0.0015^{* * *} \\
(0.0006)\end{array}$ & $\begin{array}{l}0.0000 \\
(0.0008)\end{array}$ & $\begin{array}{l}0.0008 \\
(0.002)\end{array}$ \\
\hline $\operatorname{size}\left(\gamma_{0}\right)$ & $\begin{array}{l}-0.0023^{* *} \\
(0.0012)\end{array}$ & $\begin{array}{l}-0.0026^{* *} \\
(0.0008)\end{array}$ & $\begin{array}{l}0.0168^{* *} \\
(0.0059)\end{array}$ \\
\hline size_R $\left(\gamma_{1}\right)$ & $\begin{array}{l}0.0056 \\
(0.0035)\end{array}$ & $\begin{array}{l}0.0001 \\
(0.0031)\end{array}$ & $\begin{array}{l}-0.0124^{*} \\
(0.0068)\end{array}$ \\
\hline size_M $\left(\gamma_{2}\right)$ & $\begin{array}{l}-0.0006 \\
(0.0018)\end{array}$ & $\begin{array}{l}0.0003 \\
(0.0026)\end{array}$ & $\begin{array}{l}-0.0086 \\
(0.0081)\end{array}$ \\
\hline equity $\left(\delta_{0}\right)$ & $\begin{array}{l}0.0639 * * * \\
(0.0048)\end{array}$ & $\begin{array}{l}0.0065^{*} \\
(0.0038)\end{array}$ & $\begin{array}{l}-0.1088^{* *} \\
(0.0447)\end{array}$ \\
\hline equity_R $\left(\delta_{1}\right)$ & $\begin{array}{l}0.0662 * * \\
(0.0309)\end{array}$ & $\begin{array}{l}0.0651 * \\
(0.0371)\end{array}$ & $\begin{array}{l}0.3037 * * * \\
(0.0562)\end{array}$ \\
\hline equity_M $\left(\delta_{2}\right)$ & $\begin{array}{l}-0.0368^{*} \\
(0.021)\end{array}$ & $\begin{array}{l}0.0704 \\
(0.0447)\end{array}$ & $\begin{array}{l}0.1629 * * \\
(0.0668)\end{array}$ \\
\hline $\operatorname{Tier} 1\left(\vartheta_{0}\right)$ & $\begin{array}{l}-0.0002 * * * \\
(0.0000)\end{array}$ & $\begin{array}{l}0.0000^{* * *} \\
(0.0000)\end{array}$ & $\begin{array}{l}0.0004 * * * \\
(0.0001)\end{array}$ \\
\hline Tier1_R $\left(\vartheta_{1}\right)$ & $\begin{array}{l}-0.0001 \\
(0.0001)\end{array}$ & $\begin{array}{l}-0.0001 \\
(0.0001)\end{array}$ & $\begin{array}{l}-0.0008^{* * * *} \\
(0.0001)\end{array}$ \\
\hline Tier1_M $\left(\vartheta_{2}\right)$ & $\begin{array}{l}0.0002 * * \\
(0.0001)\end{array}$ & $\begin{array}{l}-0.0001 \\
(0.0001)\end{array}$ & $\begin{array}{l}-0.0005^{* * *} \\
(0.0001)\end{array}$ \\
\hline $\operatorname{loan}\left(\xi_{0}\right)$ & $\begin{array}{l}0.0076 * * \\
(0.0037)\end{array}$ & $\begin{array}{l}0.0023 \\
(0.0017)\end{array}$ & $\begin{array}{l}0.0678^{* * * *} \\
(0.0143)\end{array}$ \\
\hline loan_R $\left(\xi_{1}\right)$ & $\begin{array}{l}0.0136 * * \\
(0.0062)\end{array}$ & $\begin{array}{l}-0.0053 \\
(0.0056)\end{array}$ & $\begin{array}{l}-0.0559^{* *} \\
(0.0191)\end{array}$ \\
\hline loan_M $\left(\xi_{2}\right)$ & $\begin{array}{l}0.013^{*} \\
(0.0074)\end{array}$ & $\begin{array}{l}-0.0142 * \\
(0.008)\end{array}$ & $\begin{array}{l}-0.0432 * \\
(0.0241)\end{array}$ \\
\hline Sargan test & $41.874(1)$ & $3.756(0.856)$ & 78.692(1) \\
\hline Hausman test & $28.624 * *$ & 7.478 & $49.169^{* * *}$ \\
\hline $\mathrm{FE} / \mathrm{RE}$ & $\mathrm{FE}$ & $\mathrm{RE}$ & $\mathrm{FE}$ \\
\hline Adj. R-squared & 0.4063 & 0.157 & 0.1586 \\
\hline$\beta_{0}+\beta_{1}+\beta_{2}$ & $-3.5181 * * *$ & - & - \\
\hline$\delta_{0}+\delta_{1}+\delta_{2}$ & $2.5191 * *$ & - & $4.7741^{* * *}$ \\
\hline
\end{tabular}


Table 8 (continued)

\begin{tabular}{llll}
\hline & NII/TA & NFC/TA & ROA \\
\hline$\vartheta_{0}+\vartheta_{2}$ & -0.6919 & - & - \\
$\vartheta_{0}+\vartheta_{1}+\vartheta_{2}$ & - & - & $-4.7717 * * *$ \\
\hline
\end{tabular}

This table estimates $Y_{i, t}=\alpha+\beta_{0}$ Post $_{t}+\sum_{k=1}^{K-1} \beta_{k}$ Post $_{t}$ BM $_{i, k}+$ $\gamma_{0} \ln \left(\right.$ TotalAssets $\left._{i, t}\right)+\sum_{k=1}^{K-1} \gamma_{k} B M_{i, k} \ln \left(\right.$ TotalAssets $\left._{i, t}\right)+\delta_{0}\left(\frac{\text { Equity }_{i, t}}{\text { TotalAssets }_{i, t}}\right)+$ $\sum_{k=1}^{K-1} \delta_{k} B M_{i, k}\left(\frac{\text { Equity }_{i, t}}{\text { TotalAssets }_{i, t}}\right)+\vartheta_{0}$ Tier $_{i, t}+\sum_{k=1}^{K-1} \vartheta_{k} B M_{i, k}$ Tier $1_{i, t}+\xi_{0}\left(\frac{\text { Loans }_{i, t}}{\text { TotalAssets }_{i, t}}\right)+$ $\sum_{k=1}^{K-1} \xi_{k} B M_{i, k}\left(\frac{\text { Loans }_{i, t}}{\text { TotalAsset }_{i, t}}\right)+\tau_{i}+\varepsilon_{i, t}$

$Y_{i, t}$ is net interest income-to-assets ratio (column NII/TA), net fees and commissions-to-assets ratio (column NFC/TA), and net income to total assets ratio (ROA) for bank $i$ at time $t . K=3$ is the number of bank business model with $k=1$ being retail bank group, $k=2$ being the market-oriented bank group and $k=3$ being the control group (wholesale banks). Post $t_{t}$ is the dummy variable that takes the value 1 from 2014 onward and 0 before that period; $B M_{i, k}$ is a dummy variable that takes the value 1 if bank $i$ belongs to the $k-t h$ business model and 0 otherwise; $\tau_{i}$ is the bank fixed effects. Robust standard errors with bank-level clustering are in brackets. The table reports also the Sargan over-identification test (with $p$-value in brackets) and the Hausman test. $\beta_{0}+\beta_{1}+\beta_{2}, \delta_{0}+\delta_{1}+\delta_{2}, \vartheta_{0}+\vartheta_{2}, \vartheta_{0}+\vartheta_{1}+\vartheta_{2}$ are the $t$-tests on the sums of the corresponding coefficients. FE/RE indicates whether the panel model is estimated with fixed effects (FE) or random effects $(\mathrm{RE}) * * *, * *, *$ denote statistical significance at $0.001,0.05$, and 0.1 level

negative impact. Bank size of the control group is negatively related to the dependent variable $\left(\gamma_{0}=-0.0023\right)$, which contrasts with the hypothesis that large banks can mitigate the effect of NIR on bank margins and profits (Molyneux et al. 2019; Altavilla et al. 2017; Chaudron 2018). Equity is significant for all groups (positive coefficient for control and retail banks and negative for market-oriented banks), with a positive combined effect $\delta_{0}+\delta_{1}+\delta_{2}$ reflecting a tendency of the interest rate margin to move in tandem with equity. Such an evidence is consistent with the cost of funding advantage argument of Gambacorta and Shin (2018), who find that an increase in the equity-toassets ratio is associated with a reduction in the overall cost of debt funding, thereby reflecting on low interest expenses and, all things equal, on higher net interest margin. As expected, loans appear to be positively related to interest rate margin for all groups, as a lending expansion/contraction leads to increased/reduced interest income. Finally, Tier 1 ratio seems to exert a margin compression for wholesale banks (the coefficient $\vartheta_{0}$ is negative), while market-oriented banks are on average less sensitive, since they show a positive differential impact on net interest margin compared to the control group. This is consistent with our arguments on the role of the regulation (Basel III) over the portfolio rebalancing for wholesale banks, which implemented a balance sheet strategy devoted to reinforce capital and liquidity requirements, thereby compressing lending and, in turn, the interest incomes. However, the combined effect $\vartheta_{0}+\vartheta_{2}$ is not statistically different from zero (the $t$-stat is -0.6919 ), and the net effect of Tier 1 ratio thus seems not to be substantial for the Italian system as a whole. 


\subsubsection{Net fees and commissions}

Differently from previous estimations, the Hausman test we run to assess which of the fixed vs. random effects model is more appropriate to investigate the net fees and commissions leads us to select the random effects panel model. According to such specification, the error component $u_{i, t}$ includes the time-invariant business modelspecific random effects $\mu_{i}$ and the individual bank random effect $v_{i, t}$, resulting in $u_{i, t}=\mu_{i}+v_{i, t}$ with $\mu_{i}$ assumed to be independent of $v_{i t}$ and both independent of covariates, namely, $\operatorname{cov}\left(X_{i t}, \mu_{i}\right)=0$ and $\operatorname{cov}\left(X_{i t}, v_{i t}\right)=0$. As a result, the model explores the "average" of bank population conditionally on bank business model instead of the "average" of each individual bank, as assumed in our fixedeffects model. The results reported in Table 8 show that wholesale banks increased fees and commissions over the period 2014-2017, though the magnitude of the coefficient is quite contained $\left(\beta_{0}=0.0008\right)$. The increase of non-interest income exhibited by the control group has been greater for small banks (the coefficient for bank size is negative) with high equity-to-assets ratio (the coefficient for equity-to-assets is positive); Tier 1, while being statistically significant, is virtually close to zero in magnitude. The business model connotation seems to matter when considering equityto-assets and loans-to-assets ratios, which are substantial, even in magnitude, for retail banks and market-oriented banks. The two groups exhibit a positive/negative (retail/market-oriented banks) sensitivity towards equity-to-assets and loans-to-assets ratios, respectively. The negative coefficient estimate of the loans control variable for market-oriented banks is consistent with our previous evidence about lending expansion ascribed to NIR policy for this business model, which suggests a scant role played by non-interest income-based activities managed by market-oriented banks, as they were characterized by more lending.

\subsubsection{Return on assets}

Taken together, our results on interest and non-interest income provide evidence that banks experiencing significant losses on loans income tried to relieve the negative effect on interest rate margin by searching for gains in non-interest-based incomes. In this regard, we are in line with Lopez et al. (2018), who find that while European and Japanese banks generally experienced significant losses over the period 2010-2016 both on lending income and "other" interest income, as effect of NIR impacts, these losses were mitigated by gains in net non-interest income. Again, Basten and Mariathasan (2018) document the experience of Swiss banks finding that retail banks have managed to maintain (and also increase) their profitability under NIR policy as lower-interest margins were offset by higher fees, though taking more risk.

To inspect the impact of NIR policy on the overall bank profitability, we regress the net income-to-assets ratio, corresponding to the Return on Assets (ROA), onto the same covariates, controls and instruments used for interest and non-interest margins. The results are presented in Table 8. The dummy variable Post is not statistically significant for any of the bank business models, indicating that the negative interest rates did not have any significant effect on the overall banking profitability. The 
results on net interest and fees and commissions margins lead us to conclude that such evidence is because banks that suffered most from net interest rate compression, primarily wholesale banks, have tried to compensate their losses through non-interest income. All controls appear to be significantly related to ROA with some business model specificities. Equity-to-assets ratio shows the higher impact in magnitude, both for the control group, with a negative coefficient on the order of -0.1088 , and the retail and market-oriented groups, which show an average differential impact of 0.3037 and 0.1629 , respectively. The combined effect of $\delta_{0}+\delta_{1}+\delta_{2}$ provides evidence (the $t$-stat is 4.7741 ) that, as a whole, higher equity positively affects banks' profitability more, thereby confirming the role of bank capital as a key determinant of bank profitability (Gambacorta and Shin 2018). This is not the case for wholesale banks, whose anomalous negative relationship between capital and net income is due to the fact that the group experienced on average a net loss over the entire period 2011-2017. The same reason explains why the coefficient estimates for the Tier 1 ratio and loans-to-assets are both positive for wholesale banks, while for retail- and market-oriented banks the average differential impacts are negative. In fact, Tier 1 ratio is expected to impact negatively on net income, as well as on lending, because of the net interest rate compression occurred with the negative interest rates. As a whole, the impact of Tier 1 on $R O A$ was negative as documented by the combined effect $\vartheta_{0}+\vartheta_{1}+\vartheta_{2}$, which is negative and statistically significant (the $t$-stat is -4.7717 ).

\subsection{Discussion}

Within the debate about the role of monetary policy on bank profitability in a low interest rate environment, our evidence about lending, security investments and liquid assets behavior expands on the empirical findings documented in the recent literature we discuss in Sect. 2. In fact, we find that high- and low-deposit banks (i.e., retail and wholesale banks) both reduced loans and increased security and liquid assets, and only market-oriented banks expanded lending, namely, those institutions characterized by low-deposit together with substantial securities. From this perspective, the highversus low-deposit characterization should move in tandem with bank assets riskiness and capital adequacy, since the portfolio reshuffling we observed for wholesale and retail banks (less lending and more securities/liquid assets) is because of the goal of reducing their risk exposures. This is in line with the "regulatory effect" discussed in Bonner (2016), whereupon banks, in the end, tend to reduce lending to the real economy because of the preferential impact in microprudential liquidity and capital regulation for government bonds. Instead, market-oriented banks, which are likewise low-deposit banks, moved towards more risk taking, as their capital adequacy was relatively high before and after the NIR policy.

These results seem to be consistent with the debt overhang argument discussed in Admati et al. (2018) and Admati and Helwig (2019). The economic reasoning of these authors points to the problems connected with leverage: since highly levered banks are reluctant to issue new equity, they are more willing to compress loans when asked to increase equity requirements, because they favor other less risk-absorbing assets. From this viewpoint, we might conjecture that wholesale banks suffered the most from 
debt overhang problems and engaged in managing their asset risk weights by investing more in securities and liquid assets, because of their less risk weights. At the same time, market-oriented banks were less affected by debt overhang problems because of their higher capital, and they thus expanded lending also in a period with negative policy rates.

These empirical findings lead us to question whether and how higher banking capital, while alleviating debt overhang problems, might help prevent the unintended consequences on lending due to negative rates ascribed to the regulatory risk-weighted asset coefficients mechanism (Basel III), also allowing banks to absorb bank profit compression and capital erosion. This question has key importance for drawing policy recommendations vis-à-vis Basel III. Specifically, whether increasing equity buffer requirement for banks combined with unconventional monetary policy could be a key approach, not only for reducing systemic risk (Hellwig 2014), but also to avoid the unintended consequences on less lending from risk weight management. In this regard, we should be extremely careful not to take regulations at face value, arriving at definitive policy messages. Indeed:

- Banks with higher capital are better managed institutions to start with, and they have a better capacity to absorb shocks; hence, it would not be surprising that they could neutralize the unintended consequences of negative rates.

- For banks with lower capital due to bad management and low profitability, if regulation mandates these banks to improve capital, it may contract their lending even more, on top of the unintended consequences of negative rates.

- Negative rates are typically implemented in bad times, and the policy message on bank capital requirement could render the tool pro-cyclical, which can slow down economic recovery even more.

Hence, before drawing definitive policy recommendations, we have to fix the above endogeneities. To do this, we need a sound structural model with clear propositions on how negative interest rates impact on the economy and bank profitability within a multiple regime setting, depending on whether the policy rate has entered the negative realm. We leave these issues to future research.

\section{Conclusions}

This paper provides empirical evidence on how the negative policy rate and prudential regulation affected Italian banks' balance sheet structures. The key findings are as follows.

First, we find that banks polarized towards retail- and market-based business models. This is ascribable to both the negative policy rates and the new regulatory framework introduced with Basel III, which induced banks to become strongly deposit-dependent and relatively more focused on trading and liquid assets. The overall increase of deposits across business models, together with the substantial reduction of risk-weighted assets, especially for retail and wholesale banks, suggest that Italian banks pursued a stabilizing funding policy in tandem with a regulatory-driven portfolio rebalancing, eventually resulting in higher financial stability. 
Second, the portfolio reshuffling we observe for wholesale and retail banks, with less lending and more securities/liquid assets, is explained by the need to reduce their risk exposures. Instead, banks with substantial trading and liquid assets, namely, the market-oriented banks, increased their lending after the negative policy rates became operational. Such a different portfolio rebalancing is strengthened by bank size and equity. The expansionary effect on credit supply was strong enough to offset the substantial lending contraction documented for the wholesale banks. The economic reason why wholesale banks reduced loans, whereas market-oriented banks did not, might be because the first group suffered the most from debt overhang problems while the second group were not affected thanks to higher capital.

Third, interest rate income compression induced by negative rates policy has been substantial for the Italian banking system as a whole, although retail banks seem to have suffered less. For all groups, the interest rate margin seems to move in tandem with equity, which is consistent with the cost of funding advantage argument of Gambacorta and Shin (2018): an increase in the equity-to-assets ratio could be associated with a reduction in the overall cost of debt funding, thereby reflecting on low interest expenses and, all things equal, on higher net interest margin.

Fourth, we document a compensatory effect played by non-interest incomes (fees and commissions) for banks that suffered most from net interest rate compression, specifically wholesale banks. The increase of non-interest income exhibited by this control group has been greater for small banks with high equity-to-assets ratio. As a whole, we can then conclude that the effect of the negative rates policy on bank profitability has been broadly neutral.

The next step in our research agenda is to inspect whether and how higher bank capital, while alleviating debt overhang problems, can help prevent the unintended consequences on lending due to negative rates.

Acknowledgments I am grateful to the referee for very helpful comments and suggestions.

Funding Open access funding provided by Università degli Studi di Brescia within the CRUI-CARE Agreement.

\section{Declaration}

Conflict of interest The authors declare that they have no conflict of interest.

Open Access This article is licensed under a Creative Commons Attribution 4.0 International License, which permits use, sharing, adaptation, distribution and reproduction in any medium or format, as long as you give appropriate credit to the original author(s) and the source, provide a link to the Creative Commons licence, and indicate if changes were made. The images or other third party material in this article are included in the article's Creative Commons licence, unless indicated otherwise in a credit line to the material. If material is not included in the article's Creative Commons licence and your intended use is not permitted by statutory regulation or exceeds the permitted use, you will need to obtain permission directly from the copyright holder. To view a copy of this licence, visit http://creativecommons.org/licenses/ by/4.0/. 


\section{Appendix}

\section{List of banks: Retail business model}

\begin{tabular}{|c|c|}
\hline Name & Legal Form \\
\hline BANCA AGRICOLA POPOLARE DI RAGUSA SCARL & POP \\
\hline BANCA CASSA DI RISPARMIO DI SAVIGLIANO SPA—BANCA CRS & SPA \\
\hline BANCA DEL PIEMONTE & $\mathrm{COOP}$ \\
\hline BANCA DEL SUD SPA & SPA \\
\hline $\begin{array}{l}\text { BANCA DI CARAGLIO, DEL CUNEESE E DELLA RIVIERA DEI FIORI—CREDITO } \\
\text { COOPERATIVO }\end{array}$ & $\mathrm{COOP}$ \\
\hline BANCA DI CREDITO COOPERATIVO DEL FRIULI CENTRALE & $\mathrm{COOP}$ \\
\hline BANCA DI CREDITO COOPERATIVO DELLA MARCA SCRL & COOP \\
\hline BANCA DI CREDITO COOPERATIVO DI BRESCIA & $\mathrm{COOP}$ \\
\hline BANCA DI CREDITO COOPERATIVO DI ROMA & $\mathrm{COOP}$ \\
\hline BANCA DI CREDITO COOPERATIVO PORDENONESE & COOP \\
\hline BANCA DI PIACENZA & POP \\
\hline BANCA DI RIPATRANSONE E DEL FERMANO CREDITO COOPERATIVO & COOP \\
\hline BANCA DI SASSARI SPA & SPA \\
\hline BANCA GALILEO SPA & SPA \\
\hline BANCA PASSADORE \& C. SPA & SPA \\
\hline BANCA PICCOLO CREDITO VALTELLINESE & POP-SPA \\
\hline BANCA POPOLARE DEL FRUSINATE & POP \\
\hline BANCA POPOLARE DEL LAZIO & POP \\
\hline $\begin{array}{l}\text { BANCA POPOLARE DELLE PROVINCE MOLISANE SOCIETA COOPERATIVA } \\
\text { PER AZIONI }\end{array}$ & POP \\
\hline BANCA POPOLARE DI BARI SOC. COOP.P.A & POP \\
\hline BANCA POPOLARE DI FONDI & POP \\
\hline BANCA POPOLARE DI PUGLIA E BASILICATA & POP \\
\hline BANCA POPOLARE DI SONDRIO SOCIETA COOPERATIVA PER AZIONI & POP \\
\hline BANCA POPOLARE SANT'ANGELO & SPA \\
\hline BANCA POPOLARE VALCONCA SCARL & POP \\
\hline BANCA PROMOS SPA & SPA \\
\hline BANCA PROSSIMA SPA & SPA \\
\hline BANCA REGIONALE DI SVILUPPO SCARL & SPA \\
\hline BANCA SELLA SPA & SPA \\
\hline BANCO DI CREDITO P. AZZOAGLIO SPA & POP \\
\hline BANCO DI DESIO E DELLA BRIANZA SPA & SPA \\
\hline BANCO DI LUCCA E DEL TIRRENO SPA & SPA \\
\hline BANCO DI NAPOLI SPA & SPA \\
\hline BANCO DI SARDEGNA SPA & SPA \\
\hline
\end{tabular}


BPER BANCA S.P.A

SPA

CARIFERMO-CASSA DI RISPARMIO DI FERMO SPA SPA

CASSA DEPOSITI E PRESTITI $\quad$ SPA

CASSA DI RISPARMIO DEL VENETO SPA $\quad$ SPA

CASSA DI RISPARMIO DI CENTO SPA $\quad$ SPA

CASSA DI RISPARMIO DI FIRENZE SPA $\quad$ SPA

CASSA DI RISPARMIO DI FOSSANO SPA $\quad$ SPA

CASSA DI RISPARMIO DI ORVIETO $\quad$ SPA

CASSA DI RISPARMIO IN BOLOGNA SPA-CARISBO SPA

CREDIT AGRICOLE CARISPEZIA S.P.A $\quad$ SPA

CREDIT AGRICOLE FRIULADRIA SPA SPA

DEUTSCHE BANK SPA $\quad$ SPA

IBL ISTITUTO BANCARIO DEL LAVORO SPA SPA

UNIPOL BANCA SPA $\quad$ SPA

The table reports the list of banks with corresponding legal form according to the Italian regulation classified as retail. SPA is public limited bank (società per azioni), COOP is cooperative bank (banca di credito cooperativo) and POP is popular bank (banca popolare).

\section{List of banks: Market-oriented business model}

\begin{tabular}{ll}
\hline Name & Legal Form \\
\hline ALETTI \& C. BANCA DI INVESTIMENTO MOBILIARE SPA & SPA \\
ALLIANZ BANK FINANCIAL ADVISORS SPA & SPA \\
BANCA 5 SPA & SPA \\
BANCA ALPI MARITTIME CREDITO COOPERATIVO CARRU & COOP \\
BANCA CAPASSO ANTONIO SPA & SPA \\
BANCA DEL CENTROVENETO_CREDITO COOP. SCRL_LONGARE (VI) & SPA \\
BANCA DEL MEZZOGIORNO_MEDIOCREDITO CENTRALE S.P.A & SPA \\
BANCA DI SCONTO E CONTI CORRENTI DI S. MARIA CAPUA VETERE SPA & SPA \\
BANCA FINNAT EURAMERICA SPA & SPA \\
BANCA GENERALI SPA & SPA \\
BANCA IFIS SPA & SPA \\
BANCA IMI SPA & SPA \\
BANCA INTERPROVINCIALE SOCIETA PER AZIONI & SPA \\
BANCA MEDIOLANUM SPA & SPA \\
BANCA POPOLARE DEL CASSINATE & POP \\
BANCA PROFILO SPA & SPA \\
\hline
\end{tabular}




\begin{tabular}{ll} 
BANCA REALE SPA & SPA \\
BANCA SANTA GIULIA SPA & SPA \\
CASSA CENTRALE BANCA CREDITO COOPERATIVO DEL NORD EST SPA & COOP \\
CASSA DI RISPARMIO DI BIELLA E VERCELLI-BIVERBANCA & SPA \\
CASSA DI SOVVENZIONI E RISPARMIO FRA IL PERSONALE DELLA BdI & SPA \\
CREDITO COOPERATIVO FRIULI-SOCIETA COOPERATIVA & COOP \\
DEXIA CREDIOP SPA & SPA \\
EXTRABANCA SPA & SPA \\
ICCREA BANCA SPA-ISTITUTO CENTRALE DEL CREDITO COOPERATIVO & COOP \\
IMPREBANCA SPA & SPA \\
MPS CAPITAL SERVICES BANCA PER LE IMPRESE SPA & SPA \\
RAIFFEISEN LANDESBANK SUEDTIROL A.G & SPA \\
SUEDTIROL BANK AG-ALTO ADIGE BANCA SP A & SPA \\
\hline The table reports the list of banks with corresponding legal form according to the Italian regulation classified \\
$\begin{array}{l}\text { as market-oriented. SPA is public limited bank (società per azioni), COOP is cooperative bank (banca di } \\
\text { credito cooperativo) and POP is popular bank (banca popolare). }\end{array}$
\end{tabular}

\section{List of banks: Wholesale business model}

\begin{tabular}{ll}
\hline Name & $\begin{array}{l}\text { Legal } \\
\text { Form }\end{array}$ \\
\hline B.C.C. DEL GARDA DI CREDITO COOPERATIVO COLLI MORENICI DEL GARDA & COOP \\
BANCA CARIGE SPA & SPA \\
BANCA CENTROPADANA—CREDITO COOPERATIVO SCRL & COOP \\
BANCA DEL MONTE DI LUCCA SPA & SPA \\
BANCA DEL TERRITORIO LOMBARDO & SPA \\
BANCA DELLA NUOVA TERRA SPA & SPA \\
BANCA DI CREDITO COOPERATIVO AGROBRESCIANO & COOP \\
BANCA DI CREDITO COOPERATIVO DELL'OGLIO E DEL SERIO & COOP \\
BANCA DI CREDITO COOPERATIVO DI CARATE BRIANZA & COOP \\
BANCA DI CREDITO COOPERATIVO DI CHERASCO & COOP \\
BANCA DI CREDITO POPOLARE SCRL & POP \\
BANCA DI FILOTTRANO- CREDITO COOPERATIVO DI FILOTTRANO E DI & COOP \\
CAMERANO- SOCIETA COOPERATIVA & \\
BANCA DI IMOLA SPA & SPA \\
BANCA MEDIOCREDITO DEL FRIULI VENEZIA GIULIA SPA & SPA \\
BANCA MONTE DEI PASCHI DI SIENA SPA & SPA \\
\hline
\end{tabular}


BANCA NAZIONALE DEL LAVORO SPA

SPA

BANCA POPOLARE DELL'ALTO ADIGE SPA

POP

BANCA POPOLARE DI CORTONA

POP

BANCA POPOLARE DI LAJATICO

POP

BANCA POPOLARE PUGLIESE

POP

BANCA SAN GIORGIO E VALLE AGNO CREDITO COOPERATIVO DI FARA

COOP VICENTO

BANCA VALDICHIANA CREDITO COOPERATIVO DI CHIUSI E MONTEPULCIANO

COOP

BANCA VALSABBINA SOCIETA COOPERATIVA PER AZIONI

POP

BANCAPULIA SPA

SPA

CASSA DEI RISPARMI DI FORLI E DELLA ROMAGNA SPA SPA

CASSA DI RISPARMIO DI BOLZANO SPA SPA

CASSA DI RISPARMIO DI BRA SPA SPA

CASSA DI RISPARMIO DI CESENA SPA SPA

CASSA DI RISPARMIO DI RAVENNA SPA SPA

CASSA DI RISPARMIO DI SALUZZO SPA SPA

CASSA DI RISPARMIO DI VOLTERRA SPA SPA

CASSA RURALE ALTA VALSUGANA BANCA DI CREDITO COOPERATIVO COOP

CASSA RURALE ALTO GARDA-BANCA DI CREDITO COOPERATIVO COOP

CASSA RURALE ED ARTIGIANA DI BRENDOLA-CREDITO COOPERATIVO COOP

CASSA RURALE ED ARTIGIANA DI CANTU-BANCA DI CREDITO COOPERATIVO COOP

CREDIT AGRICOLE CARIPARMA SPA SPA

CREDITO COOPERATIVO DI CARAVAGGIO ADDA E CREMASCO—CASSA COOP

RURALE SOCIETA COOPERATIVA

CREDITO EMILIANO SPA $\quad$ SPA

CREDITO PADANO-BANCA DI CREDITO COOPERATIVO S.C COOP

EMIL BANCA-CREDITO COOPERATIVO SOCIETA COOPERATIVA COOP

FARBANCA SPA

FINDOMESTIC BANCA SPA SPA

INTESA SANPAOLO SPA

MEDIOCREDITO ITALIANO SPA SPA

MEDIOCREDITO TRENTINO-ALTO ADIGE SPA SPA

SANFELICE 1893 BANCA POPOLARE SOCIETA COOPERATIVA PER AZIONI $\quad$ POP

UNICREDIT SPA SPA

UNIONE DI BANCHE ITALIANE SCPA SPA

The table reports the list of banks with corresponding legal form according to the Italian regulation classified as wholesale. SPA is public limited bank (società per azioni), COOP is cooperative bank (banca di credito cooperativo) and POP is popular bank (banca popolare). 


\section{B. Variable description}

\begin{tabular}{ll}
\hline Variable & Description \\
\hline loans & Mortgages and loans to non-financial firms \\
trading assets & Total earning assets excluding loans \\
liquid assets & Cash due from banks, trading securities and at fair value through \\
& income, loans and advances to banks, reverse repos and cash \\
& collaterals \\
retail deposits & Total customer deposits \\
interbank funding & Deposits from banks \\
long term funding & Long-term market-based funding instruments \\
equity & Bank's capital \\
Tier 1 & Bank's core equity capital to its total risk weighted assets \\
Risk Weighted Assets (RWA) & Bank's total exposure to risk \\
Net Interest Income (NII) & Net interest margin computed as the difference between interest \\
& earning assets and interest bearing liabilities \\
Net Fees and Commissions (NFC) & Net fees and commission from non-interest income revenues \\
Net Income & After tax net profit \\
Operating Income & Operating income includes: Net interest income, dividends and \\
& other income from equity investments, net fees and \\
commissions, net trading income, other expenses/income
\end{tabular}

This table reports variables and description used in the sample

\section{References}

Abbassi, P., Iyer, R., Peydro, J.L., Tous, F.: Securities trading by banks and credit supply: micro-evidence. J. Financ. Econ. 121(3), 569-594 (2016)

Admati, A.A., DeMarzo, P.M., Hellwig, M.F., Pfleiderer, P.: The leverage ratchet effect. J. Finance 73(1), 145-198 (2018)

Admati, A.A., Hellwig, M.F.: The Parade of the Bankers' New Clothes Continues: 34 Flawed Claims Debunked. Rock Center for Corporate Governance at Stanford University Working Paper no. 143 (2019)

Aiyar, S., Calomiris, C., Hooley, J., Korniyenko, Y., Wieladek, T.: The international transmission of bank capital requirements: evidence from the UK. J. Financ. Econ. 113(3), 368-386 (2014)

Albertazzi, U., Nobili, A., Signoretti, F.: The Bank Lending Channel of Conventional and Unconventional Monetary Policy. Bank of Italy Working Paper no. 1094/2016 (2016)

Altavilla, C., Pariès, M.D., Nicoletti, G.: Loan supply, credit markets and the euro area financial crisis. J. Bank. Finance 109, 105658 (2019)

Altavilla, C., Boucinha, M., Peydro, J.L.: Monetary Policy and Bank Profitability in a Low Interest Rate Environment. European Central Bank, Frankfurt ECB Working Paper no 2105/2017 (2017)

Altunbas, Y., Manganelli, S., Marques-Ibanez, D.: Bank Risk During the Financial Crisis: Do Business Models Matter? ECB Working Paper no. 1394/2011 (2011)

Amzallag, A., Calza, A., Georgarakos D., Sousa, J.: Monetary Policy Transmission to Mortgages in a Negative Interest Rate Environment, ECB Working Paper no. 2243/2019 (2019) 
Angbazo, L.: Commercial bank net interest margin, default risk, interest rate risk, and off-balance sheet banking. J. Bank. Finance 21(1), 57-87 (1997)

Arce, O., García-Posada, M., Mayordomo, S., Ongena, S.: Adapting Lending Policies when Negative Interest Rates Hit Banks' Profits. Banco De Espana Documentos de Trabajo no. 1832/2018 (2018)

Ayadi, R., De Groen, W.P.: Bank business models monitor 2014 Europe. Centre for European Policy Studies, $1-68$ (2014)

Ayadi, R., Arbak, E., De Groen, W.P.: Business Models in European Banking: A Pre and Post Crisis Screening. Centre for European Policy Studies (CEPS), Brussels (2011)

Basten, C., Mariathasan M.: How Banks Respond to Negative Interest Rates: Evidence from the Swiss Exemption Threshold, CESifo Working Paper no 6901/2018 (2018)

Berger, A., Udell, G.: Relationship lending and lines of credit in small firm finance. J. Business $\mathbf{6 8}(3)$, 351-381 (1995)

Bernanke, B.S.: What Tools Does the Fed Have Left? Part 1: Negative Interest Rates. Brookings Institution (blog). https://www.brookings.edu/blog/ben-bernanke/2016/03/18/what-tools-doesthe-fed-have-left-part-1-negative-interest-rates/ (2016)

Bernanke, B.S., Blinder, A.S.: Credit, money, and aggregate demand. Am. Econ. Rev. 78(2), 435-439(1988)

Bernanke, B.S., Blinder, A.S.: The federal funds rate and the channels of monetary transmission. Am. Econ. Rev. 82(4), 901-921 (1992)

Bernanke, B.S., Gertler, M.: Inside the black box: the credit channel of monetary policy transmission. J. Econ. Perspect. 9(4), 27-48 (1995)

Bonner, C.: Preferential regulatory treatment and banks' demand for government bonds. J. Money Credit Bank. 48(6), 1195-1221 (2016)

Boot, A., Thakor, A.V.: The accelerating integration of banks and markets and its implications for regulation. In: Berger, A., Molyneux, P., Wilson, J. (eds.) The Oxford Handbook of Banking, pp. 58-90. Oxford University Press, Oxford (2010)

Borio, C.E.V., Gambacorta, L., Hofmann, B.: The Influence of Monetary Policy on Bank Profitability. BIS Working Paper no. 514/2015 (2015)

Bottero, M., Minoiu, C., Peydró, J.L., Polo, A., Presbitero, A.F., Sette, E.: Negative Monetary Policy Rates and Portfolio Rebalancing: Evidence from Credit Register Data. Universitat Pompeu Fabra Barcelona Working Paper No. 1649 (2019)

Brunnermeier, M.K., Koby, Y.: The Reversal Interest Rate: An Effective Lower Bound on Monetary Policy. Princeton University Working Paper (2019)

Campos, U.M.: Going Negative at the Zero Lower Bound: The Effects of Negative Nominal Interest Rates. Federal Reserve Bank of San Francisco Working Paper No 2019-2021 (2019)

Chaudron, R.F.D.D.: Bank's interest rate risk and profitability in a prolonged environment of low interest rates. J. Bank. Finance 89, 94-104 (2018)

Claessens, S., Coleman, N., Donnelly, M.: Low-for-long interest rates and banks' interest margin and profitability: cross-country evidence. J. Financ. Intermed. 35, 1-16 (2018)

Conti, A.M., Nobili, A., Signoretti, F.M.: Bank Capital Constraints, Lending Supply and Economic Activity. Bank of Italy Working Paper No. 1199/2018 (2018)

Demiralp, S., Eisenschmidt, J., Vlassopoulos, T.: Negative Interest Rates, Excess Liquidity and Bank Business Models: Banks' Reaction to Unconventional Monetary Policy in the Euro Area. ECB Working Paper No. 2283/2019 (2019)

Demirguc-Kunt, A., Huizinga, H.: Bank activity and funding strategies: the impact on risk and returns. J. Financ. Econ. 98(3), 626-650 (2010)

Eggertsson, G.B., Juelsrud, R.E., Summers, L.H., Getz, E.: Negative Nominal Interest Rates and the Bank Lending Channel. Norges Bank Research Working Paper No. 4/2019 (2019)

Eisenschmidt, J., Smets, F.: Negative Interest Rates: Lessons from the Euro Area. In: Aguirre, A., Brunnermeier, M., Saravia, D. (eds.) Monetary Policy and Financial Stability: Transmission Mechanisms and Policy Implications, pp. 13-42. Central Bank of Chile, Santiago, Chile (2019)

Farné, M., Vouldis, A.: Business Models of the Banks in the Euro Area, ECB Working Paper Series, No. 2070 (2017)

Fraisse, H., Lé, M., Thesmar D.: The Real Effects of Bank Capital Requirements. Management Science, forthcoming (2019)

Gambacorta, L., Mistrulli, P.E.: Does bank capital affect lending behavior? J. Financ. Intermed. 13, 436-457 (2004) 
Gambacorta, L., Shin, H.S.: Why bank capital matters for monetary policy. J. Financ. Intermed. 35, 17-29 (2018)

Gambacorta, L., Marques-Ibanez D.: The Bank Lending Channel. Lessons from the Crisis. BIS Working Papers no. 1335/2011 (2011)

Gomez, M., Landier, A., Sraer, D. Thesmar, D.: Banks' Exposure to Interest Rate Risk and The Transmission of Monetary Policy. Journal of Monetary Economics, forthcoming (2020)

Goodhart, C., Kabiri, A.: Monetary Policy and Bank Profitability in a Low Interest Rate Environment: A Follow-up and a Rejoinder, CEPR Discussion Papers, No. 13752 (2019)

Grossmann, D., Scholz, P.: The golden rule of banking: funding cost risks of bank business models. J. Bank. Regul. 20, 174-196 (2019)

Heider, F., Saidi, F., Schepens, G.: Life below zero: bank lending under negative policy rates. Rev. Financ. Stud. 32(10), 3727-3761 (2019)

Hellwig, M.F.: Systemic risks and macro-prudential policy. In: Houben, A., Kijskens, R., Teunissen, M. (eds.) Putting macroprudential policy to work, occasional studies 12-7, pp. 42-77. De Nederlandse Bank, Amsterdam (2014)

Jiménez, G., Ongena, S., Peydró, J., Saurina, J.: Credit supply and monetary policy: identifying the bankbalance sheet channel with loan applications. Am. Econ. Rev. 102(5), 2121-2165 (2012)

Jiménez, G., Ongena, S., Peydró, J., Saurina, J.: Hazardous times for monetary policy: what do twenty-three million bank loans say about the effects of monetary policy on credit risk-taking? Econometrica 82(2), 463-505 (2014)

Kashyap, A.K., Stein, J.C.: What do a million observations on banks say about the transmission of monetary policy? Am. Econ. Rev. 90(3), 407-428 (2000)

Kashyap, A.K., Stein, J.C.: The Impact of Monetary Policy on Bank Balance Sheets. In Carnegie-Rochester Conference Series on Public Policy no. 42, pp. 151-195 (1995)

King, M.R.: The Basel III net stable funding ratio and bank net interest margins. J. Bank. Finance 37(11), 4144-4156 (2013)

Kishan, R.P., Opiela, T.P.: Bank size, bank capital and the bank lending channel. J. Money Credit Bank. 32(1), 121-141 (2000)

Kumhof, M., Wang, X.: Banks, Money, and the Zero Lower Bound on Deposit Rates (August 20, 2020). Tinbergen Institute Discussion Paper 2020-050/VI (2020)

Lopez, J.A., Rose, A.K., Spiegel, M.M.: Why Have Negative Nominal Interest Rates Had Such a Small Effect on Bank Performance? Cross Country Evidence. Federal Reserve Bank of San Francisco Working Paper no. 2018-07 (2018)

Lucas, A., Schaumburg, J., Schwaab, B.: Bank business models at zero interest rates. J. Business Econ. Stat. 37(3), 542-555 (2019)

Maudos, J., de Guevara, J.F.: Factors explaining interest margin in the banking sectors of the european union. J. Bank. Finance 28(9), 2259-2281 (2004)

Mian, A., Sufi, A.: The consequences of mortgage credit expansion: evidence from the U.S. mortgage default crisis. Quarterly J. Econ. 124(4), 1449-1496 (2009)

Michelangeli, V., Sette, E.: How Does Bank Capital Affect the Supply of Mortgages? Evidence From a Randomized Experiment. BIS Working Papers no. 557/2016 (2016)

Mirzaei, A., Moore, T., Liu, G.: Does market structure matter on bank's profitability and stability? Emerging vs. advanced economies. J. Bank. Finance 37(8), 2920-2937 (2013)

Mishkin, F., Eakins, S.: Financial Markets and Institutions, 6 ed., Pearson Prentice Hall (2009)

Molyneux, P., Reghezza, A., Xie, R.: Bank margins and profits in a world of negative rates. J. Bank. Finance 107, 105613 (2019)

Myers, S.C.: Determinants of corporate borrowing. J. Financ. Econ. 5(2), 147-175 (1977)

Nucera, F., Lucas, A., Schaumburg, J., Schwaab, B.: Do negative interest rates make banks less safe? Econ. Lett. 159, 112-115 (2017)

Petersen, M.A., Rajan, R.G.: The benefits of lending relationships: evidence from small business data. J. Financ. 49(1), 3-37 (1994)

Popov, A., Van Horen, N.: The Impact of Sovereign Debt Exposure on Bank Lending: Evidence from the European Debt Crisis. DNB Working Paper no. 382/2013 (2013)

Rajan, R.G.: Has Financial Development Made the World Riskier? Proceedings of the Economic Policy Symposium, Jackson Hole, Federal Reserve Bank of Kansas City, 313-69 (2005)

Roengpitya, R., Tarashev, N., Tsatsaronis, K.: Bank Business Models. BIS Quarterly Review, December, 55-65 (2014) 
Saunders, A., Schumacher, L.: The determinants of bank interest rate margins: an international study. J. Int. Money Financ. 19(6), 813-832 (2000)

Stiroh, K.J.: Diversification in Banking. In A. Berger, A., Molyneux, P., Wilson, J., (eds.), The Oxford Handbook of Banking, pp. 146-171. Oxford University Press, Oxford (2010).

Van den Heuvel, S.J.: The Bank Capital Channel of Monetary Policy. 2006 Meeting Papers 512, Society for Economic Dynamics (2006)

Wheelock, D.C., Wilson, P.W.: Why do banks disappear? The determinants of U.S. bank failures and acquisitions. Rev. Econ. Stat. 82(1), 127-138 (2000)

Publisher's Note Springer Nature remains neutral with regard to jurisdictional claims in published maps and institutional affiliations. 